\title{
A Journey through Development of Inland Waterways in India
}

\author{
Aditya Gupta \\ College of Management and Economic Studies \\ University of Petroleum Energy Studies, Dehradun, India \\ Neeraj Anand \\ College of Management and Economic Studies \\ University of Petroleum Energy Studies, Dehradun, India \\ A K Bansal \\ Inland Waterways Authority of India (IWAI)
}

\begin{abstract}
Inland Waterways (IWT) is the finest mode of transportation available.With lowest capital cost, low running cost and low maintenance cost the cost of moving goods through this mode is just a fraction of other modes like Road and Rail.On top of this IWT is an environment friendly mode with least external costs.India has been blessed with long navigable waterways in excess of 14000 KM.However, post-independence IWT never got the desired attention resulting in IWT share of total transportation a meagre $0.4 \%$.This prompted the authors to evaluate the progress of IWT since independence, the various challenges being faced and suggest possible steps to increase IWT share in India. The paper outlines the various waterways in India, the governance structure to manage IWT, various policies and programs undertaken by Indian authorities to promote IWT, a comparison of Indian IWT with US, China and EU, the key barriers in growth and future recommendations.
\end{abstract}

\section{INTRODUCTION}

"I am the river, sit and listen to my wisdom" Ian Menard 1994. River symbolizes freedom, growth, transformation, perseverance and most importantly, movement. Rivers have a very large role to play in development of human civilization. The 5000 year old Egyptian civilization was completely built around river Nile. The great Giza pyramids would not have built without movement of blocks of stone through river Nile

Inland Waterways Transport (IWT) is the transportation of cargo over rivers, backwaters, canals and creeks. Among all modes of transportation in a country, it is the most inexpensive mode of transportation due to following reasons:

a) Low Capital Cost: Being a natural mode, Inland Waterways does not require a large development cost like road construction or Rail-Track lying. Estimates show that developing and building an inland waterway costs about 5-10 per cent to that of 4-lane highway/railway [1].

b) Fuel efficient: Water transportation is always considered to be the most cost efficient transportation mode. It is estimated that one litre fuel can transport 24 tonne $/ \mathrm{km}$ freight by road, 85 tonne/km by rail and 105 tonne/km by waterways [1].

c) Least maintenance cost: Maintenance cost of IWT is assessed at $20 \%$ that of road. [1] 
IWT is safest, most economical and environment friendly mode of transport. It offer less resistance to traction at reasonable speed and enjoys low maintenance cost as channels are almost natural [2].

The total external costs of inland navigation after accounting for all externalities, including accidents, congestion, noise emissions, air pollution and other environmental impacts are seven times lower than that of road transport [3].

\section{History of IWT in India.}

Archaeologists have found a burnt brick basin at Lothal, Gujarat India built during the Indus Valley Civilization in about 2400BC, which is the earliest known dock found in the world, connecting Harrapan towns with Arabian sea through ancient course of Sabarmati river [4]. For centuries, Ganges and its principal tributaries servers route of trade and commerce [5]. Ancient Greek historian, Megasthenes quotes that, Ganges and its main tributaries were navigated from 4BC and inland navigation flourished then [6]. Kautilya (4th Century BC) in his Arthashastra wrote extensively about navigation, boat sizes, port charges, ferry regulation laws, expeditions, the duties of the state and the workforce and trade and taxation in the days of the Mauryan Empire [7]. Riverine traffic was dominant in the Mughal period; available records suggest trade between Agra and Satgam in Bengal. Mirzapur, Varanasi, Patna and Munger were important ports from where smaller vessels could ship their goods on the bigger ones [7].

Even during the period of British rule the Brahmaputra and Barak-Surma rivers were used extensively for transport and trade between northeast India and the port of Kolkata. With the growth of the tea industry these rivers became important carriers of trade. The East India Company started the water route along the Brahmaputra from Kolkata to Dibrugarh way back in 1844. A regular fortnightly steamer service operated between Kolkata and Agra on the river Yamuna and by 1863 three similar services were operating between Kolkata and Assam. River services up the river Ganga extended as far as Garhmukteshwar, $645 \mathrm{~km}$ above Allahabad, and Ayodhya, $325 \mathrm{~km}$ up the river Ghaghara [107]. At the peak in 1877 as many as 180,000 country cargo boats were registered at Kolkata, 124,000 at Hooghly and 62,000 at Patna. However during end of 19th century and early part of twentieth century, the British Government started neglecting inland navigation, in favour of road and railway transport and irrigation projects, by the state led to the consumptive use of river water; as flow reduced, river-beds started silting up. The Assam earthquakes of 1897 and 1950 and the Bihar earthquake of 1934 caused many upheavals in the river beds of the Brahmaputra and tributaries of the Ganga, severely impairing drainage: navigation through these rivers was more stressed [7].

\section{IWT potential in India}

India has an estimated $14500 \mathrm{~km}$ of navigable inland waterways, including river systems, canals, backwaters, creeks and tidal inlets that can effectively support mechanized crafts. About $5200 \mathrm{~km}$ of major rivers and $485 \mathrm{~km}$ of canals are suitable for inland transport [9].

This mode is extensively used for transportation in many countries. IWT contributes about $8.5 \%$ of total cargo movement in USA, about $8.3 \%$ in China, $38 \%$ in Netherlands, $24 \%$ in Belgium and $13 \%$ in Germany [10]. However, in India the progress on IWT is far from satisfactory. IWT enjoys a share of less $0.5 \%$ in the total transportation in the country. It has been estimated that diversion of one billion tonne-km of cargo to the IWT mode will reduce transport fuel costs by 5 million USD and the overall transport costs by 9 million USD [2, 11].A $10 \%$ share of IWT in total transportation could reduce India's transportation bill by at least Rs 10,000 crores or USD 1.8 Billion. 
In spite of carrying a rich history of river based transportation, wide array of river system, the apparent advantages of Inland Waterways still the share of IWT in India has been dismal.

This prompted authors to two central research questions:

RQ1. What is the progress made by India in IWT sector since Independence?

RQ2. What are the challenges which have been hindering the growth and what at possible suggestions to overcome them?

\section{Research Methodology}

To address research question one, a detailed survey has been made of published literature and statistics on Inland Water Transport in India to understand the historical development, the progress made since independence, the governance structure, various agencies involved in this sector, the various policy initiatives taken by Indian Government to promote this sector.

To address research question two, semi structured interviews have been conducted with various players in the IWT sector, namely officials of IWAI, Shippers, Barge owners and operators and Industry experts. The interviews brought insights on the challenges faced by Inland Waterways Industry in India and highlighted some of the recommendations to promote and progress in this sector.

\section{Physical features and Traffic utilisation}

The inland water transport sector did not get the attention it deserved until 1980, when a National Transport Policy Committee, headed by B D Pandey, found funding to this sector was grossly inadequate [7]. The National Transport Policy Committee (1980) [8] recom $\neg$ mended the following principles for declaration of a national waterway.

a) It should possess capability of navigation by mechanically propelled vessels of a reasonable size.

b) It should have about $45 \mathrm{~m}$ wide channel and minimum $1.5 \mathrm{~m}$ depth.

c) It should be a continuous stretch of $50 \mathrm{kms}$. The only excep 7 tion to be made to waterway length is for urban conglomeraᄀtions and intra-port traffic.

d) It should pass through and serve the interest of more than one State (or).

e) It should connect a vast and prosperous hinterland and Major Ports (or).

f) It should pass through a strategic region where development of navigation is considered necessary to provide logistic support for national security (or).

g) It should connect places not served by any other modes of transport.

Based on the above principles, five National Waterways have been declared by Indian Government till 2015. The details of the 5 declared waterways are as per table 1 [1]. The Indian Parliament has approved a bill in 2016 declaring another 106 waterways as National Waterways across the country. Figure 1 to 5 indicates the 5 waterways in greater detail and figure 6 indicates all 5 NWs on Indian map. Though not declared as National Waterway one of the most commercially significant IWT in India is the tidal river system in Goa, comprising the Zuari and Mandovi rivers and the Cumbarjua Canal [12]. 
Table 1: A comparison of 5 National Waterways

\begin{tabular}{|c|c|c|c|c|c|}
\hline & $\begin{array}{l}\text { National } \\
\text { Waterway } 1 \\
\end{array}$ & $\begin{array}{l}\text { National } \\
\text { Waterway } 2\end{array}$ & $\begin{array}{l}\text { National } \\
\text { Waterway } 3\end{array}$ & $\begin{array}{l}\text { National } \\
\text { Waterway } 4 \\
\end{array}$ & $\begin{array}{l}\text { National } \\
\text { Waterway } 5 \\
\end{array}$ \\
\hline $\begin{array}{l}\text { Year of } \\
\text { declaration }\end{array}$ & 1986 & 1988 & 1993 & 2008 & 2008 \\
\hline $\begin{array}{l}\text { Rivers } \\
\text { and Path }\end{array}$ & $\begin{array}{l}\text { The Ganga - } \\
\text { Bhagirathi - } \\
\text { Hooghly river } \\
\text { system between } \\
\text { Haldia (Sagar) \& } \\
\text { Allahabad }\end{array}$ & $\begin{array}{l}\text { The river } \\
\text { Brahmaputra } \\
\text { between } \\
\text { Bangladesh } \\
\text { Border and } \\
\text { Sadiya }\end{array}$ & $\begin{array}{l}\text { 168-km West } \\
\text { Coast canal } \\
\text { (Kottapuram- } \\
\text { Kollam) } \\
\text { segment, the } \\
23-\mathrm{km} \\
\text { Udyogmandal } \\
\text { canal-Kochi } \\
\text { Pathalam } \\
\text { bridge portion } \\
\text { and the 14-km } \\
\text { Champakara } \\
\text { canal (Kochi- } \\
\text { Ambalamugal) }\end{array}$ & $\begin{array}{l}\text { This consists } \\
\text { of the } \\
\text { Kakinada- } \\
\text { Puducherry } \\
\text { stretch of } \\
\text { canals, the } \\
\text { Kaluvelly } \\
\text { tank- } \\
\text { Bhadrachalam- } \\
\text { Rajahmundry } \\
\text { stretch of the } \\
\text { river Godavari } \\
\text { and the } \\
\text { Wazirabad- } \\
\text { Vijayawada } \\
\text { stretch of the } \\
\text { river Krishna. }\end{array}$ & $\begin{array}{l}\text { The Talcher- } \\
\text { Dhamra } \\
\text { stretch of } \\
\text { river } \\
\text { Brahmani, } \\
\text { Geonkhali- } \\
\text { Charbatia } \\
\text { stretch of } \\
\text { East Coast } \\
\text { Canal, } \\
\text { Charbatia- } \\
\text { Dhamra } \\
\text { stretch of } \\
\text { Matai river } \\
\text { and } \\
\text { Mangalgadi- } \\
\text { Paradip } \\
\text { stretch of } \\
\text { Mahanadi } \\
\text { delta rivers }\end{array}$ \\
\hline $\begin{array}{l}\text { Length in } \\
\mathrm{KM}\end{array}$ & 1620 & 891 & 205 & 1027 & 623 \\
\hline $\begin{array}{l}\text { States in } \\
\text { passes } \\
\text { through }\end{array}$ & $\begin{array}{l}\text { UP, Bihar, West } \\
\text { Bengal }\end{array}$ & Assam & Kerala & $\begin{array}{l}\text { Andhra } \\
\text { Pradesh, Tamil } \\
\text { Naidu, } \\
\text { Pondicherry }\end{array}$ & $\begin{array}{l}\text { West Bengal } \\
\text { and Orissa }\end{array}$ \\
\hline $\begin{array}{c}\text { Least } \\
\text { Available } \\
\text { Depth in } \\
\text { meters }\end{array}$ & $\begin{array}{c}\text { Haldia (Sagar) - } \\
\text { Farakka }(560 \mathrm{Km}) \\
-3 \mathrm{~m} \\
\text { Farakka - Barh } \\
(400 \mathrm{KM})-2.5 \mathrm{~m} \\
\text { Barh - Ghazipur } \\
(290 \mathrm{KM})-2 \mathrm{~m} \\
\text { Ghazipur - } \\
\text { Chunar/Allahabad } \\
(370 \mathrm{KM})-1.5 \mathrm{~m}\end{array}$ & $\begin{array}{c}\text { Bangladesh } \\
\text { Border - Pandu } \\
(255 \mathrm{~km})- \\
2.5 \mathrm{~m} \text {; Pandu- } \\
\text { Neamati (374 } \\
\text { Km) - 2.5m; } \\
\text { Neamati- } \\
\text { Dibrugarh(139 } \\
\text { km) - 2m; } \\
\text { Dibrugarh- } \\
\text { Oriumghat ( } 92 \\
\text { Km) - } 1.5 \mathrm{~m}\end{array}$ & $\begin{array}{c}2 \text { meters has } \\
\text { been provided } \\
\text { in the entire } \\
\text { NW-3 }\end{array}$ & $\begin{array}{c}\text { Under } \\
\text { Development }\end{array}$ & $\begin{array}{c}\text { Under } \\
\text { Development. } \\
\text { To maintain } \\
\text { LAD of } 2 \mathrm{~m} \\
\text { in the } \\
\text { Brahmani } \\
\text { river all } \\
\text { through the } \\
\text { year. }\end{array}$ \\
\hline
\end{tabular}




\begin{tabular}{|c|c|c|c|c|c|}
\hline $\begin{array}{l}\text { Aids to } \\
\text { navigation }\end{array}$ & $\begin{array}{l}\text { The day } \\
\text { navigation is } \\
\text { provided in entire } \\
\text { stretch of NW-1 } \\
\text { all-round the } \\
\text { year. The night } \\
\text { navigational is } \\
\text { available on large } \\
\text { part of NW1. }\end{array}$ & $\begin{array}{l}\text { Day navigation } \\
\text { marks with } \\
\text { bamboos and } \\
\text { navigational } \\
\text { lights fixed on } \\
\text { country boats / } \\
\text { beacons have } \\
\text { been provided } \\
\text { from } \\
\text { Bangladesh } \\
\text { Border to } \\
\text { Dibrugarh }\end{array}$ & $\begin{array}{l}\text { The entire } \\
\text { route length of } \\
\text { NW-3 has been } \\
\text { provided with } \\
\text { aids } \quad \text { to } \\
\text { facilitate } 24 \\
\text { hours } \\
\text { navigation }\end{array}$ & & \\
\hline Terminals & $\begin{array}{c}\text { Floating terminals } \\
\text { at } 20 \text { locations } \\
\text { and four } \\
\text { permanent } \\
\text { terminals a } \\
\text { Kolkata, Gaighat } \\
\text { Patna, Farakka } \\
\text { and Pakur. }\end{array}$ & $\begin{array}{c}\text { One fixed } \\
\text { terminal at } \\
\text { Pandu and } 10 \\
\text { floating } \\
\text { terminals }\end{array}$ & $\begin{array}{l}\text { Total } 11 \\
\text { locations } \\
\text { envisaged. } \\
\text { Nine have } \\
\text { already been } \\
\text { constructed. } \\
\text { Remaining two } \\
\text { locations under } \\
\text { construction. } \\
\end{array}$ & & \\
\hline $\begin{array}{l}\text { Type of } \\
\text { cargo } \\
\text { moved }\end{array}$ & $\begin{array}{l}\text { Cement, Fly Ash, } \\
\text { Iron Ore, Coal, } \\
\text { Tyres, Steel Plain } \\
\text { Sheet, Stone } \\
\text { Chips, Petroleum } \\
\text { Products, Grains } \\
\text { Aluminium block, } \\
\text { Coke, Cooking } \\
\text { coal, ODC. }\end{array}$ & $\begin{array}{l}\text { Bamboo, } \\
\text { Bamboo } \\
\text { products, Coal, } \\
\text { Plant \& } \\
\text { machinery, } \\
\text { Cement, } \\
\text { Building } \\
\text { material, } \\
\text { fertilizer, Food } \\
\text { grains, Milk \& } \\
\text { other essential } \\
\text { commodities }\end{array}$ & $\begin{array}{l}\text { Phosphoric } \\
\text { Acid, Sulphur, } \\
\text { Zinc, Furnace } \\
\text { oil, Rock } \\
\text { Phosphate, } \\
\text { Various } \\
\text { commodities in } \\
\text { containers, } \\
\text { Furnace oil- } \\
\text { bunkering, } \\
\text { POL(bunkering } \\
\text { to ships), } \\
\text { Potable water }\end{array}$ & & \\
\hline $\begin{array}{l}\text { Cargo } \\
\text { movement } \\
\text { in Million } \\
\text { MT in } \\
\text { Year } \\
\text { 2013-14 }\end{array}$ & 31.72 & 24.53 & 9.58 & $\begin{array}{l}\text { Under } \\
\text { Development }\end{array}$ & $\begin{array}{l}\text { Under } \\
\text { Development }\end{array}$ \\
\hline Map & Refer figure 1 & Refer figure 2 & Refer figure 3 & Refer figure 4 & Refer figure 5 \\
\hline
\end{tabular}




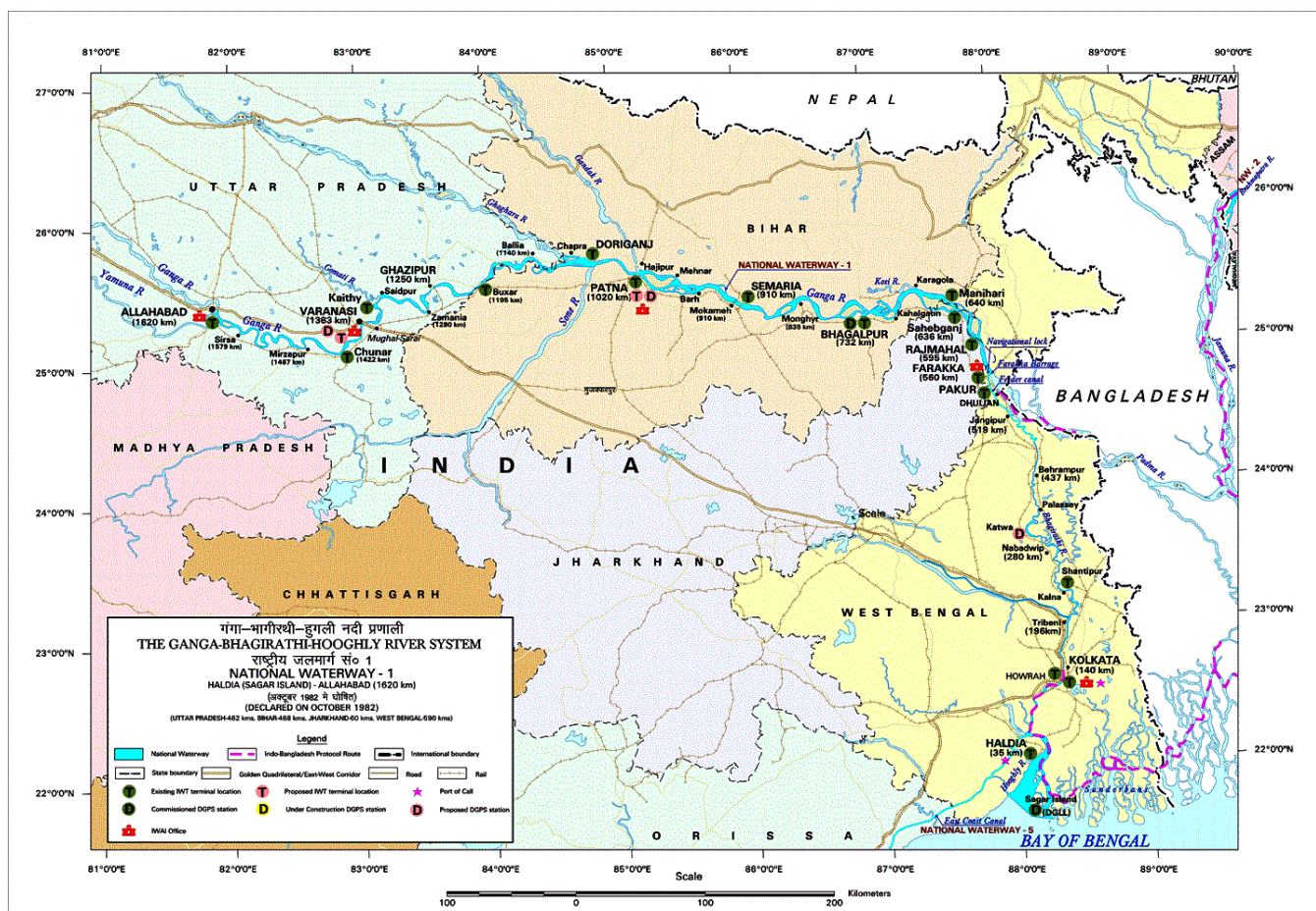

Figure 1 - National Waterway 1

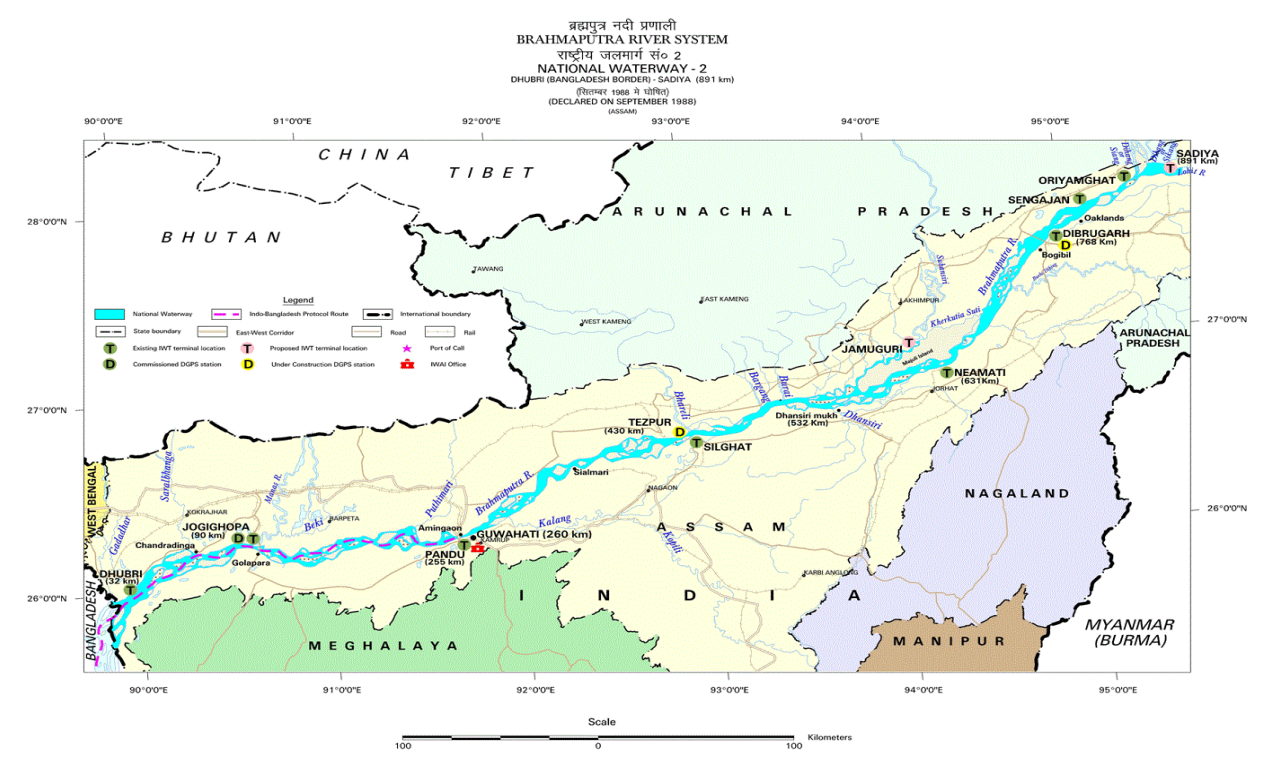

Figure 2 - National Waterway 2. 


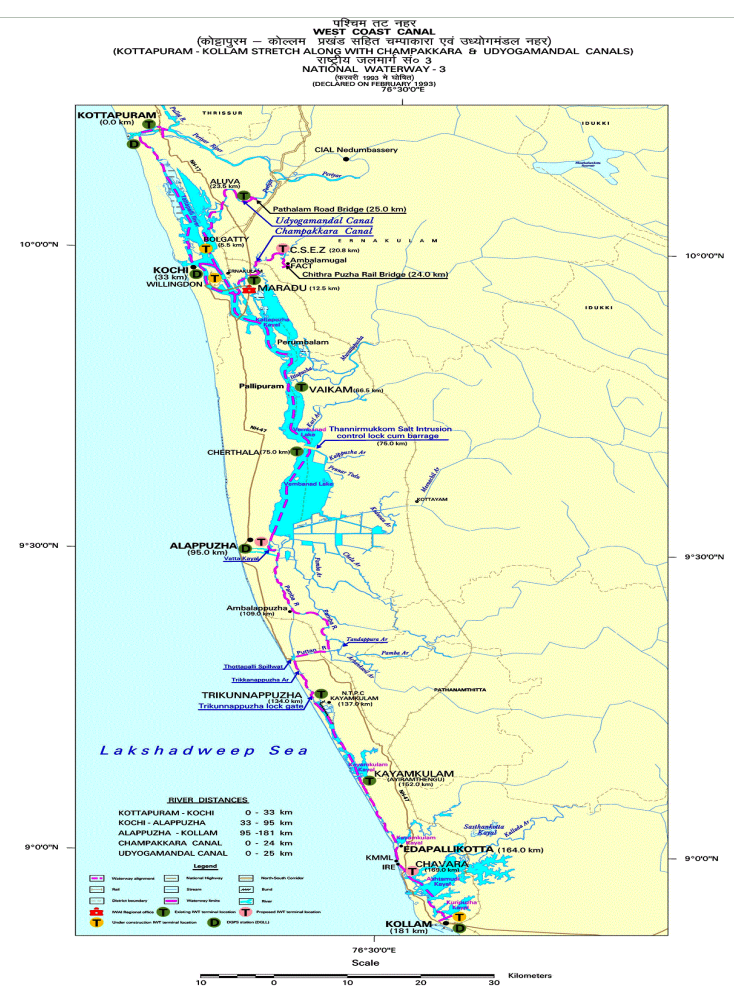

Figure 3 - National Waterway 3

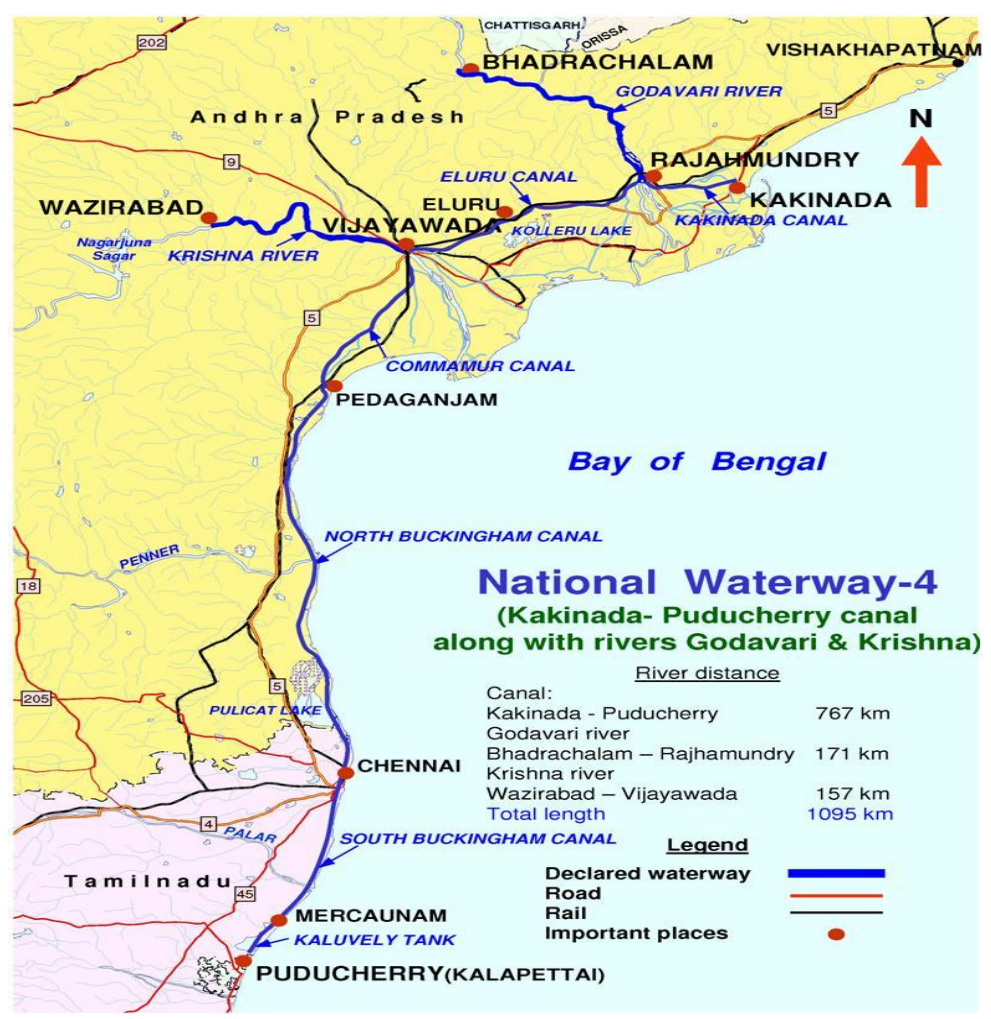

Figure 4 - National Waterway 4 


\section{National Waterway-5}

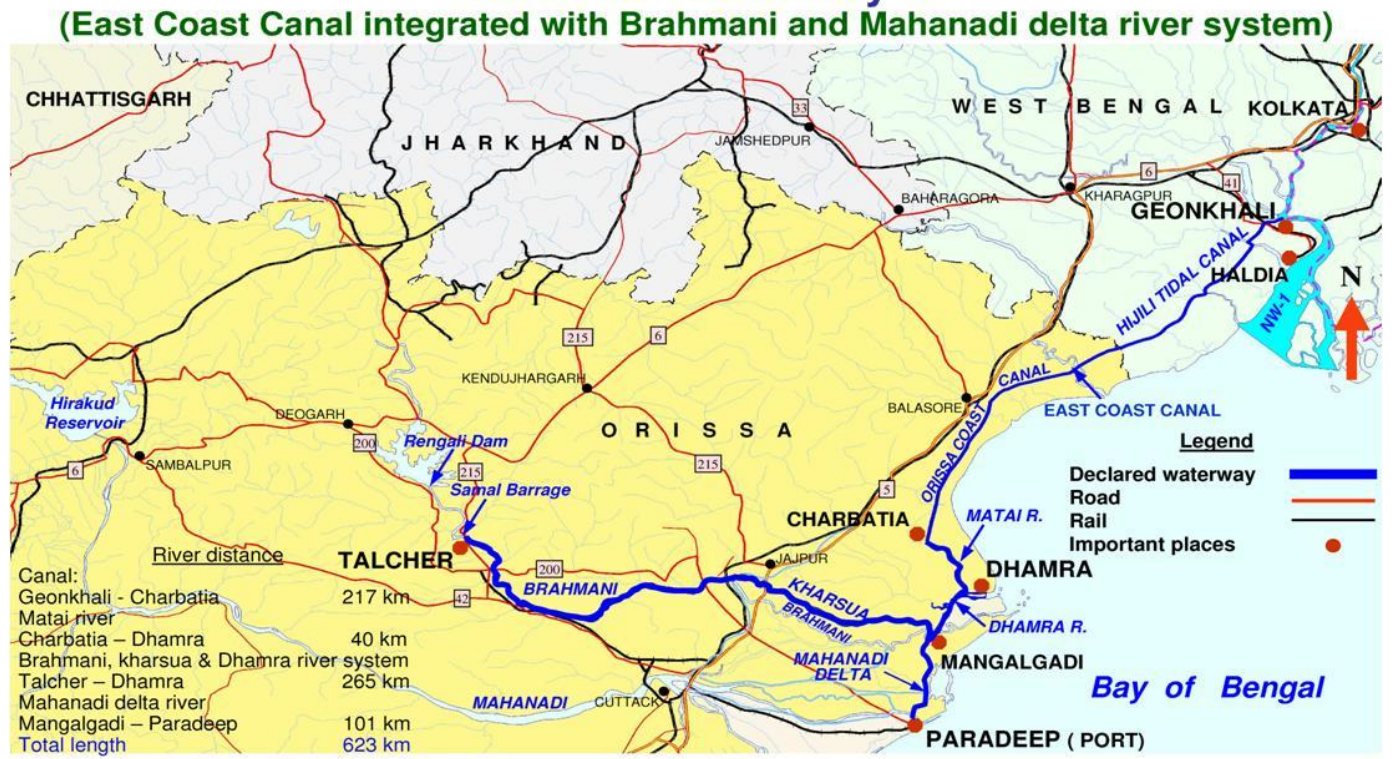

Figure 5 - National Waterway 5

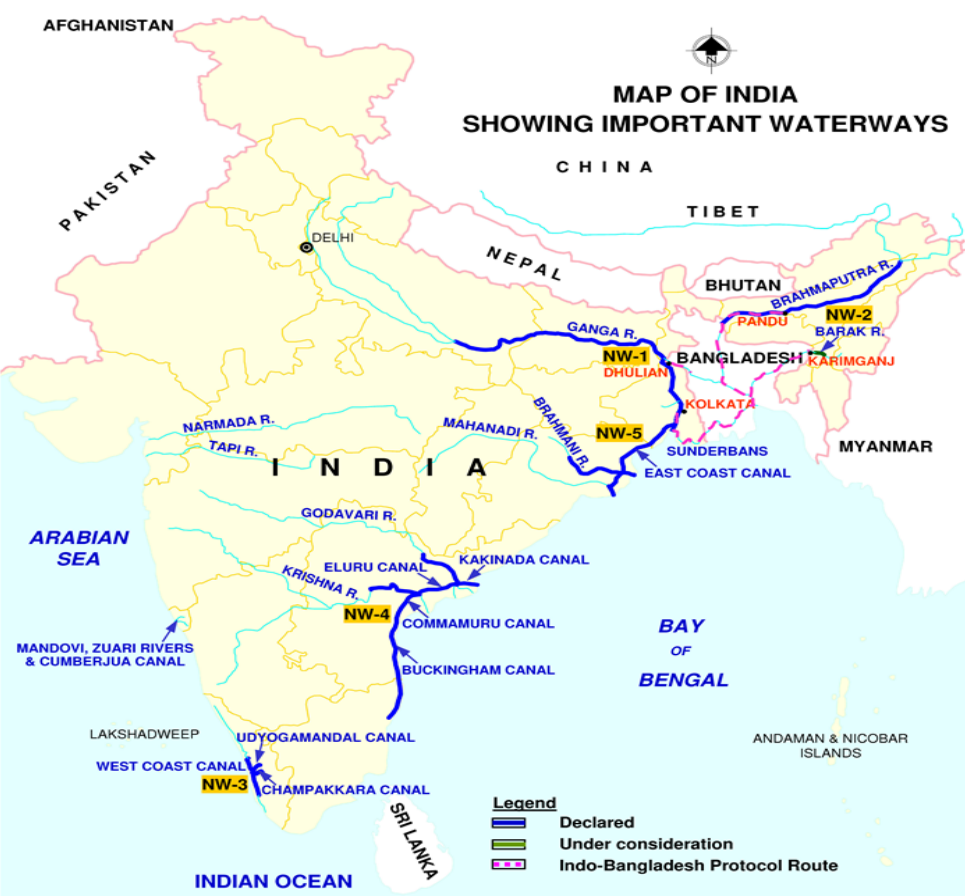

Figure 6 - All National Waterways on Indian Map

\section{LENGTH OF WATERWAYS INCLUDING COMPARISON WITH OTHER COUNTRIES}

The following table indicates the total length of waterways in India and how it compares with other countries.

Table 2: Waterways Length in KMs

\begin{tabular}{|l|l|l|l|l|}
\hline & US & EU & China & India \\
\hline Designated Waterways & 40,000 & 35,000 & 61,000 & 4,400 \\
\hline $\begin{array}{l}\text { Commercially } \\
\text { Significant }\end{array}$ & 16,000 & 8,000 & 24,000 & 2,900 \\
\hline
\end{tabular}

In case of India, The NW1, 2, 3 The Goa and Mumbai Waterways are considered as commercially significant. 


\section{Classification of waterways}

The Indian Government have classified Waterways, as under, based on the LAD, Width and bend radius.

Table 3: Classification of Waterways in India.

\begin{tabular}{|c|c|c|c|c|c|c|c|c|c|c|c|c|c|c|}
\hline & \multicolumn{5}{|c|}{ River } & \multicolumn{5}{|c|}{ Canal } & \multicolumn{4}{|c|}{ Vessel } \\
\hline $\begin{array}{l}\text { Class of } \\
\text { Waterway }\end{array}$ & $\begin{array}{l}\text { Waterway } \\
\text { minimum } \\
\text { Depth in m }\end{array}$ & $\begin{array}{l}\text { Waterway } \\
\text { minimum } \\
\text { Width in m }\end{array}$ & \begin{tabular}{|l} 
Bend \\
radius in \\
meter
\end{tabular} & $\begin{array}{l}\text { Vertical } \\
\text { clearance } \\
\text { between } \\
\text { piers in } \\
\text { metres }\end{array}$ & $\begin{array}{l}\text { Horizontal } \\
\text { clearance } \\
\text { between } \\
\text { piers in } \\
\text { metres }\end{array}$ & $\begin{array}{l}\text { Waterway } \\
\text { minimum } \\
\text { Depth in m }\end{array}$ & $\begin{array}{l}\text { Waterway } \\
\text { minimum } \\
\text { Width in } \\
\text { m }\end{array}$ & $\begin{array}{l}\text { Bend } \\
\text { radius in } \\
\text { meter }\end{array}$ & $\begin{array}{l}\text { Vertical } \\
\text { clearance } \\
\text { between } \\
\text { piers in } \\
\text { metres }\end{array}$ & $\begin{array}{l}\text { Horizontal } \\
\text { clearance } \\
\text { between } \\
\text { piers in } \\
\text { metres }\end{array}$ & \begin{tabular}{|l} 
Tonnage \\
capacity in \\
DWT for self \\
propelled \\
Vessel
\end{tabular} & \begin{tabular}{|l} 
Dimensio \\
$n$ of \\
Vessel \\
L*B*Din \\
$m$
\end{tabular} & $\begin{array}{l}\text { Tonnage } \\
\text { capacity in DWT } \\
\text { for one tug and } \\
2 \text { barge } \\
\text { combination }\end{array}$ & $\begin{array}{l}\text { Dimension } \\
\text { of one tug } \\
\text { and } 2 \text { barge } \\
\text { combination } \\
L^{*} B^{*} \text { Din } m\end{array}$ \\
\hline 1 & 1.2 & 30 & 300 & 4 & 30 & 1.5 & 20 & 300 & 4 & 20 & 100 & $32 * 5 * 1$ & 200 & $80 * 5 * 1$ \\
\hline$\|$ & 1.4 & 40 & 500 & 5 & 40 & 1.8 & 30 & 500 & 5 & 30 & 300 & $45 * 8 * 1.2$ & 600 & $110 * 8 * 1.2$ \\
\hline III & 1.7 & 50 & 700 & 7 & 30 & 2.2 & 40 & 700 & 7 & 40 & 500 & $58 * 9 * 1.5$ & 1000 & $141 * 9 * 1.5$ \\
\hline IV & 2 & 30 & 800 & 10 & 50 & 2.5 & 50 & 800 & 10 & 50 & 1000 & $70 * 12 * 1.8$ & 2000 & $170 * 12 * 1.8$ \\
\hline V & 2 & 80 & 800 & 10 & 80 & & & & & & 1000 & $70 * 12 * 1.8$ & 4000 & $170 * 24 * 1.8$ \\
\hline $\mathrm{VI}$ & 2.75 & 80 & 900 & 10 & 80 & 3.5 & 60 & 900 & 10 & 60 & 2000 & $86 * 14 * 2.5$ & 4000 & $210 * 14 * 2.5$ \\
\hline VII & 2.75 & 100 & 900 & 10 & 100 & & & & & & 2000 & $86 * 14 * 2.5$ & 8000 & $210 * 28 * 2.5$ \\
\hline
\end{tabular}

Source: Gazette Notification date 20th to 26th January 2007, Ministry of Shipping, Road Transport and Highways [13]

\section{Modal Share}

The following chart the shares of various modes in India. The share of IWT in the total transportation pie is insignificant as of now.

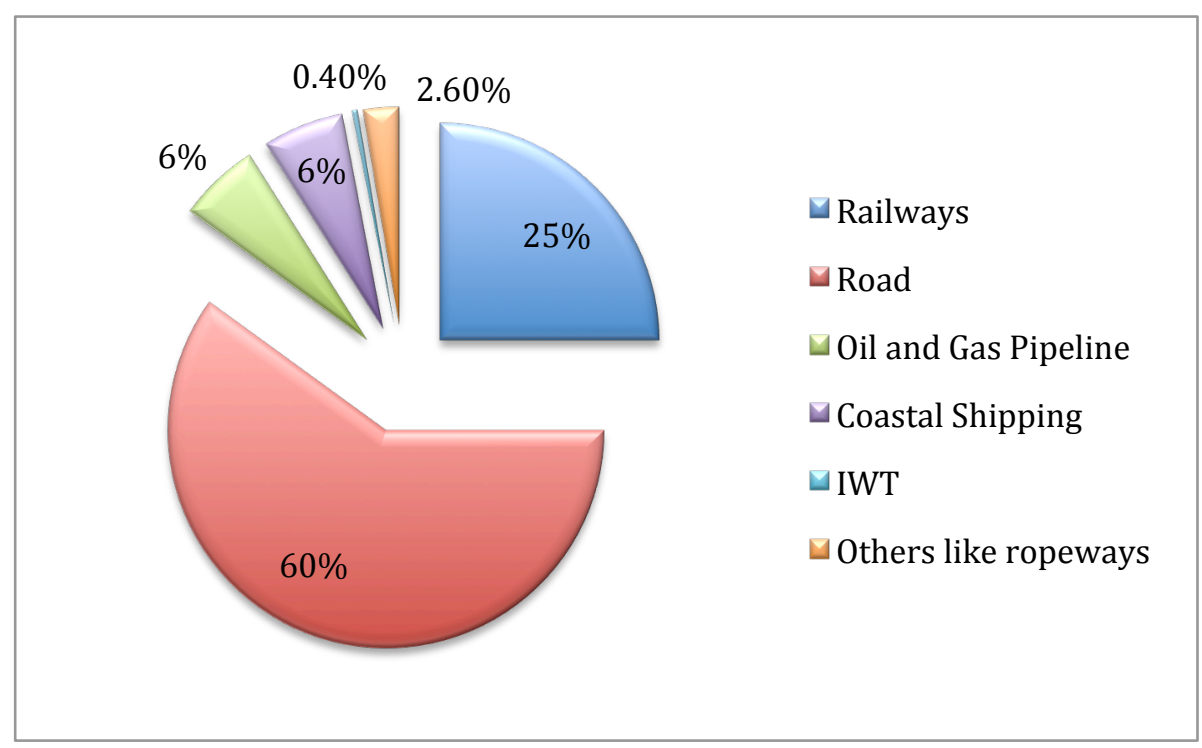

\section{Source: IWAI}

\section{Cargo Traffic}

The following table indicates the cargo carried on Indian Waterways. 
Table 4: Cargo moved on various modes

\begin{tabular}{|l|l|l|l|l|l|}
\hline & \multicolumn{5}{|l|}{ Cargo Moved ( Million Tonnes) } \\
\hline & $\begin{array}{l}\mathbf{2 0 0 9 -} \\
\mathbf{1 0}\end{array}$ & $\begin{array}{l}\mathbf{2 0 1 0}- \\
\mathbf{1 1}\end{array}$ & $\begin{array}{l}\mathbf{2 0 1 1 -} \\
\mathbf{1 2}\end{array}$ & $\begin{array}{l}\mathbf{2 0 1 2}- \\
\mathbf{1 3}\end{array}$ & $\begin{array}{l}\mathbf{2 0 1 3 -} \\
\mathbf{1 4}\end{array}$ \\
\hline $\begin{array}{l}\text { Details of Waterway } \\
\text { I }\end{array}$ & 1.84 & 1.88 & 3.31 & 2.72 & 3.35 \\
\hline $\begin{array}{l}\text { National Waterway No. } \\
\text { II }\end{array}$ & & & & & \\
\hline $\begin{array}{l}\text { National Waterway No. } \\
\text { III }\end{array}$ & 0.18 & 2.16 & 2.41 & 2.43 & 2.48 \\
\hline Sub Total NWs & 0.67 & 0.89 & 1.34 & 1.24 & 1.07 \\
\hline Goa Waterways & $\mathbf{2 . 6 9}$ & $\mathbf{4 . 9 3}$ & $\mathbf{7 . 0 6}$ & $\mathbf{6 . 3 8}$ & $\mathbf{6 . 8 9}$ \\
\hline Maharashtra Waterways & 54.43 & 55.38 & 43.47 & 10.68 & 0.60 \\
\hline Grand Total & 69.51 & 14.87 & 19.95 & 24.20 & 24.77 \\
\hline
\end{tabular}

Source: Ministry of Shipping website

\section{Commodity Types}

Following Table indicates the main types of commodities transported on IWT in India.

IWT is used mainly to transport bulk commodities like cement, coal, flyash, fertilisers, food grains and Over Dimensional Cargo (ODC).

Table 5 : Composition of Cargo Moved on National Waterways (In Million tonnes)

\begin{tabular}{|l|l|l|l|l|l|}
\hline Commodity & $\begin{array}{l}\mathbf{2 0 0 9}- \\
\mathbf{1 0}\end{array}$ & $\mathbf{2 0 1 0 -}$ & $\mathbf{2 0 1 1 -}$ & $\mathbf{2 0 1 2}-$ & $\mathbf{2 0 1 3 -}$ \\
\hline Building Material & 1.39 & 1.49 & 1.53 & 1.73 & 2.00 \\
\hline Chemicals & 0.00 & 0.10 & 0.06 & 0.09 & 0.12 \\
\hline Fertilisers & 0.25 & 0.34 & 0.31 & 0.36 & 0.30 \\
\hline Food items & 0.20 & 0.15 & 0.15 & 0.49 & 0.41 \\
\hline Mix & 0.03 & 0.09 & 2.15 & 0.56 & 0.62 \\
\hline Ore/Minerals & 0.08 & 0.06 & 0.02 & 0.30 & 0.14 \\
\hline $\begin{array}{l}\text { POL/POL } \\
\text { Products }\end{array}$ & 0.41 & 0.49 & 0.42 & 0.34 & 0.24 \\
\hline Coal & 0.00 & 0.00 & 0.00 & 0.08 & 0.56 \\
\hline Iron \& Steel & 0.00 & 0.00 & 0.00 & 0.00 & 0.01 \\
\hline Miscellaneous & 0.33 & 2.21 & 2.43 & 2.44 & 2.49 \\
\hline Total & $\mathbf{2 . 6 9}$ & $\mathbf{4 . 9 3}$ & $\mathbf{7 . 0 6}$ & $\mathbf{6 . 3 8}$ & $\mathbf{6 . 8 9}$ \\
\hline
\end{tabular}

Source: Ministry of Shipping website

\section{GOVERNANCE STRUCTURE FOR IWT AND INSTITUTIONS}

India is a federal republic governed under a parliamentary system and consists of 29 states and 7 union territories.

\section{Institutional Framework}

The following are the main institutions involved in policy and administration of IWT in India.

\section{Ministry of Shipping}

The Ministry of Shipping, a branch of the Government of India, is the apex body for formulation and administration of the rules and regulations and laws relating to Shipping. The Ministry of 
Shipping encompasses within its fold shipping and ports sectors which include shipbuilding and ship-repair, major ports, national waterways, and inland water transport. Ministry of Shipping has been entrusted with the responsibility to formulate policies and programmes on these subjects and their implementation [14].

\section{The Inland Waterways Authority of India (IWAI)}

The Inland Waterways Authority of India (IWAI) came into existence on 27th October 1986 for development and regulation of inland waterways for shipping and navigation. The Authority primarily undertakes projects for development and maintenance of IWT infrastructure on national waterways through grant received from Ministry of Shipping. The head office of the Authority is at Noida. The Authority also has its regional offices at Patna, Kolkata, Guwahati and Kochi and sub-offices at Allahabad, Varanasi, Bhaglapur, Farakka, Hemnagar, Dibrugarh (Assam), Kollam, Chennai, Bhubaneswar and Vijayawada(A.P.). The key responsibilities of IWAI are $[1,15]$ :

a) Infrastructure development \& regulation of NWs

b) Techno- economic feasibility studies

c) Proposals for declaration of new NWs

d) Advise Central Government on IWT matters

e) Assistance to States in IWT development

f) Classification of waterways

\section{Central Inland Water Transport Corporation Limited (CIWTC)}

Central Inland Water Corporation Limited (CIWTC LTD) was incorporated in May 1967 as a Govt. of India Undertaking after taking over the business from a loss making erstwhile sterling company, namely River Steam Navigation \& Co. (RSN \& Co.). It is under the administrative control of Ministry of Shipping (MOS), Govt. of India. The main activities were transportation of cargo in the rivers in the Eastern India \& North-Eastern India and on the Indo-Bangladesh protocol routes. Operate \& Maintain terminals [16]. With effect from August 2016, Government has decided to close down CIWTC due to continuous losses [17].

\section{The National Inland Navigation Institute (NINI)}

The National Inland Navigation Institute (NINI) has been set up by Inland Waterways Authority of India (IWAI) at Patna, Bihar in February 2004 with a view to develop human resource for the Inland Water Transport sector including development, maintenance and management of waterways. The institute imparts quality training on various aspects of inland water transportation namely development \& management of waterways, surveying \& dredging of waterways, design \& construction of terminals, design \& construction of vessels, Technical \& commercial operation of vessels, running of vessels, terminal management, and trafficmanagement.

The institute provides refresher and upgradation education to existing professionals in river engineering, dredging, surveying, Hydrography, repair \& maintenance of inland vessels.

The institute provides training at three levels namely induction, upgradation and professional development for vessel operations. The training provided at NINI is fully residential for trainees seeking fresh employment in the sector [18].

\section{State Governments}

IWAI mainly plans, builds and manages National Waterways. Beside National Waterways the local waterways are being managed by various State Governments. The Ministry of Shipping 
has also launched a scheme called Central Sector Scheme for the North Eastern State which allows 100\% subsidy for any projects implemented by state government for IWT sector.

\section{Legal Framework}

\section{Act 1917}

Act 1917 provides for the State Governments to frame Rules regarding the survey and registration of Inland Mechanically propelled vessels. Any Indian National can own and operate the vessel anywhere in the country if registered under the I.V. Act [11].

\section{IWAI Act 1985}

a) Section 12 of the IWAI Act 1985 empowers the Inland Waterways Authority to enter into and perform any contract necessary for the discharge of its functions under the Act.

b) Section 14 of the IWAI Act empowers the Authority to provide or permit setting up of infrastructure facilities for national waterways.

c) Section 17 of the IWAI Act provides for the Authority, with the previous approval of the Central Govt. to levy fees and charges at such rates as may be laid down by regulations made in this behalf for services or benefits rendered in relation to the use of the National Waterways for the purposes of shipping, navigation infrastructural facilities including facilities relating to the berthing of vessels, loading of cargo and storage of cargo. The fees and charges levied shall be collected in such manner as may be determined by regulation. ("Regulations" means regulations made by the Authority under the IWAI Act, 1985).

d) Section 19 (1) (c) provides for crediting to the "IWAI Fund" all sums received by the Authority from such other sources as may be decided upon by the Central Govt [111].

\section{National Waterways Act, 2016 [Wikipedia]}

The Act came into force from April 2016. The Act merges 5 existing Acts which have declared the 5 National Waterways and proposes 106 additional National Waterways. The Bill identifies total 111 waterways as national waterways [19]. The Schedule of the Bill also specifies the extent of development to be undertaken on each waterway. The Bill repeals the five Acts that declare the existing national waterways [20]. These five national waterways are now covered under the Bill. The Statement of Objects and Reasons of the Bill states that while inland waterways are recognised as a fuel efficient, cost effective and environment friendly mode of transport, it has received lesser investment as compared to roads and railways. Since inland waterways are lagging behind other modes of transport, the central government has evolved a policy for integrated development of inland waterways. 
Table 6: Participation of Government Agencies, Public \& Private Sector Enterprises in IWT/NW development [12]

\begin{tabular}{|c|c|c|c|c|}
\hline $\begin{array}{l}\text { Vessels / } \\
\text { Terminals }\end{array}$ & \begin{tabular}{|l|} 
Construction, \\
Operation \\
Maintenance
\end{tabular} & $\begin{array}{l}\text { Government } \\
\text { Agencies }\end{array}$ & $\begin{array}{ll}\text { Public } & \text { Sector } \\
\text { Enterprises } & \end{array}$ & $\begin{array}{l}\text { Private Sector } \\
\text { Enterprises }\end{array}$ \\
\hline Waterway & $\begin{array}{l}\text { Constructing of } \\
\text { waterway }\end{array}$ & IWAI & CIWTC in Sundarbans & - \\
\hline Waterway & $\begin{array}{l}\text { Maintenance of } \\
\text { Waterway }\end{array}$ & IWAI & Subcontracted Dredging & $\begin{array}{l}\text { Subcontracted } \\
\text { Dredging }\end{array}$ \\
\hline Waterway & Navigational Support & IWAI & $\begin{array}{l}\text { Ports, near port areas } \\
\text { GPS suppliers (KPT, } \\
\text { Port of Panaji) }\end{array}$ & - \\
\hline $\begin{array}{l}\text { Carriers } \\
\text { (Vessels) }\end{array}$ & Vessel Manufacturing & - & $\begin{array}{l}\text { CIWTC, Hooghly Docks, } \\
\text { Garden Reach } \\
\text { Shipbuilders } \\
\text { Engineers (GRSE) }\end{array}$ & Several \\
\hline $\begin{array}{l}\text { Carriers } \\
\text { (Vessels) }\end{array}$ & Vessel ownership & IWAI & $\begin{array}{l}\text { CIWTC/KSINCL and } \\
\text { others }\end{array}$ & Several \\
\hline $\begin{array}{l}\text { Carriers } \\
\text { (Vessels) }\end{array}$ & $\begin{array}{l}\text { Vessel } \\
\text { maintenance/repair }\end{array}$ & - & $\begin{array}{l}\text { CIWTC/KSINCL and } \\
\text { others }\end{array}$ & Several \\
\hline $\begin{array}{l}\text { Carriers } \\
\text { (Vessels) }\end{array}$ & Vessel Operation & - & $\begin{array}{l}\text { CIWTC/KSINCL and } \\
\text { others }\end{array}$ & Several \\
\hline $\begin{array}{l}\text { Terminals } \\
\text { (Jetties) }\end{array}$ & Terminal construction & $\begin{array}{l}\text { IWAI and } \\
\text { State } \\
\text { Government }\end{array}$ & $\begin{array}{l}\text { Mormugao Port Trust, } \\
\text { CIWTC }\end{array}$ & Several \\
\hline $\begin{array}{l}\text { Terminals } \\
\text { (Jetties) }\end{array}$ & Terminal operation & - & Mormugao Port Trust & Several \\
\hline
\end{tabular}

\section{NATIONAL FIVE YEAR PLANS}

Five-Year Plans (FYP's) are integrated nationalized economic programs which lay the foundation plans for economy growth of a country. Planning Commission is responsible for development, execution and monitoring of FYP's in India [21]. India's first 5 year national plan was released in year 1951 and we are now in the 12thFYP (2013-17).

\section{1st to 5th FYP (1950 to 1980)}

Limited progress happened on Inland Waterways during first to fifth FYP from 1950 to 1980. The key developments which happened during this period are listed below [22, 23, 24, 25, and 26]:

\section{Farakka Barrage}

The Farakka barrage was constructed in the 1970s to reduce siltation in river Hooghly, which was causing great problems in the operation of Kolkata port due to reduced draft between Haldia and Kolkata. Prior to its construction, the line of navigation from Patna to Assam was through the rivers Ganga, Padma and Jamuna, linking the river Brahmaputra at Dhubri. This route was also utilised by vessels plying between Kolkata and Assam. To enable navigation from Farakka to Kolkata, a lock was also constructed. With the commissioning of the navigation lock joining the main river and the feeder canal, the navigation route linking the Ganga and Bhagirathi was opened in November 1987[7] 


\section{Establishment of Central Inland Water Transport Corporation Limited (CIWTC)}

The Joint Steamer Companies i.e. India General Steam Navigation Co. and Rivers Steam Navigation Co. were made a P.S.U. in 1967 as Central Inland Water Transport Corporation Limited (CIWTC). The main activities are transportation of cargo in the rivers in the Eastern India \& North-Eastern India and on the Indo-Bangladesh protocol routes. Operate \& Maintain terminals [16].

\section{India-Bangladesh protocol}

This protocol was signed in 1972 between the two countries. Under this protocol, India and Bangladesh agreed to use inland waterways for passage of goods between two places of one country through the territory of the other and also for inter-country trade. The protocol provides for 50:50 sharing on tonnage basis for inter-country and transit cargo by Indian and Bangladeshi vessels.

\section{6th FYP (1980-85)}

The inland water transport sector did not get the attention it deserved until 1980, when a National Transport Policy Committee, headed by B D Pandey, found funding to this sector was grossly inadequate. Moreover, whatever was allotted was not utilised. The committee that no institution, government or the private sector, was willing to tap the potential of the sector [7]. The concept of 'national waterway' was introduced in 1982 to boost inland water transport $[27,28]$.

\section{7th FYP (1985-90)}

The main developments during the Seventh Plan were [29]:

Establishment of Inland Waterways Authority of India (IWAI)

The momentous development during seventh FYP was the establishment of Inland Waterways Authority of India (IWAI) on 27 October 1986, to develop and regulate inland waterways for shipping and navigation.

\section{Declaration of National Waterway 1}

The first National Waterway was declared in October 1986. The declaration was very significant as it showed the intent of the Government to seriously develop IWT as a mode. Declaring a river stretch as National Waterway meant a focused approach about development, allocation of funds, project being identified and executed and allowing a navigable path round the year.

\section{Declaration of National Waterway 2}

NW2 on Brahmaputra was declared in September 1988. The Indian North Eastern region has a disadvantage of being connected to main India through a very small region also known as Chicken Neck. Declaration of NW2 had another objective of creating an alternate method of connecting NE with mainland India.

\section{8th FYP (1992-97)}

The main developments during the Eigth Plan were [29, 30]:

During 8th FYP a total of Rs 331 crores was allocated to IWT sector. Out of this money Rs 152 only was spent. The money spend was mainly on NW1 and NW2 to increase the depth, creation of fairways, setting up terminals and setting up navigational aids on both these National Waterways. 


\section{Declaration of National Waterway 3}

The West Coast Canal from Kottapuram to Kollam was declared as National Waterway No.3 vide National Waterway Act 1992 (33-F of 1992) and notified on 1st Feb. 1993. From Kottapuram to Kollam including Champakara and Udyogmandal canals with a navigable length of $205 \mathrm{kms}$.

\section{9th FYP (1997-2002)}

The main developments during the Nineth Plan were [30, 31]:

Release of IWT Policy was the most significant thing to happen in Nineth FYP. The policy:

a) Indicated that the potential of IWT could be as large as 50 BTKM.

b) Indicated that each shift of one BTKM of cargo to IWT will save the country at least Rs 45 in transportation cost.

c) Recognised that budgetary support is not enough to revive IWT. It requires support from public sector units and private sector. The private sector has a crucial role to play in the development of the sector.

d) Indicated guidelines and various schemes for private participation in IWT sector.

e) Authorized IWAI for joint ventures and equity participation in BOT projects.

a) Recognised the need to develop Human capital for IWT sector.

b) Recognised the need to interlink waterways with various ports.

National Waterway No.1.

a) Navigable depth of 2 metres was maintained throughout the year on the stretch from Haldia to Farakka (560 kms) and from Farakka to Patna (460 kms) for about 330 days in a year.

b) Permanent terminal facilities created at Kolkata, Pakur and Farakka.

c) Floating terminal facilities created at Haldia, Kolkata, Karagola, Bhagalpur, Munger, Patna, Ballia and Allahabad.

d) Night navigation facilities being provided in the Kolkata- Farakka stretch In National Waterway No.2.

a) Depth of 2 metres was maintained between Dhubri and Pandu (260 kms) for about 330 days a year.

b) The Waterway route from Calcutta to Guwahati (Pandu) covering about $1500 \mathrm{kms}$ was made navigable round the year with 1.8 metre draft vessels.

c) Provision of night navigational facilities between Dhubri and Guwahati was implemented.

d) Floating terminal facilities were provided at Dhubri, Jogighopa, Pandu, Tezpur and Neamati.

e) Warehousing facility is available at Pandu Terminal.

Inland Water Transport has been accorded the status of infrastructure under Section 80 IA of Income Tax Act so as to enable it to avail itself of concessions applicable to other infrastructure sector.

\section{0th FYP (2002-2007)}

The main developments during the Tenth Plan were [31,32]:

1. An outlay of Rs 903 crores was approved for IWT sector in Tenth FYP.

2. The main developments during Tenth FYP were on maintenance of fairway including procurement of vessels for channel development (dredgers, survey launches etc), 
setting up of terminals, provision of navigational aids, procurement of cargo vessels for demonstration purpose etc for the three national waterways, techno-economic feasibility studies on other waterway systems.

\section{NW1}

Waterways: Projects were identified and implemented in the 10th Plan period to provide a navigational channel of $45 \mathrm{~m}$ bottom width and $3 \mathrm{~m}$ depth in the Haldia-Farakka stretch, $45 \mathrm{~m}$ bottom width and $2 \mathrm{~m}$ depth in the Farakka-Varanasi portion and $30 \mathrm{~m}$ bottom width and 1.5 $\mathrm{m}$ depth in the Varanasi- Allahabad stretch. These included annual fairway development measures such as bandalling and channel marking, dredging, river training measures, hydrographic surveys, procurement of vessels such as dredging units, tug-cum-buoy lying vessels, survey vessels, repair of vessels and constructing regional offices at Haldia, Kolkata and Patna [7].

Navigational Aids: Navigational marks for day navigation were provided all round the year. Night navigation aids were provided between Tribeni and Farakka $(364 \mathrm{~km}$ ) during the 10th Plan and these were maintained [7].

Vessels: In the 10th Plan period, therefore, IWAI acquired different types of vessels for operation on NW-1 to dredge shoals, for talweg and detailed surveys, inspection and monitoring field works [7].

\section{NW2}

Fairway Development: River conservancy works (bandalling and dredging) to maintain navigable depth were taken up on year-to-year basis. LAD of $2 \mathrm{~m}$ between Dhubri and Dibrugarh was maintained for most parts of the years during the 10th Plan period. [7]

Navigational aids: The target was to provide day navigation aids in the entire waterway and night navigation aids in the Dhubri-Guwahati sector by the end of the 10th Plan. Navigational marks for day navigation were provided in the entire waterway all-round the year. Night navigation aids were provided during the 10th Plan between Bangladesh border and Pandu with the help of manned country boats [7].

Terminals: A project to construct a fixed RCC terminal at Pandu (Guwahati), capable of handling containers, was sanctioned during the 10th Plan and this was almost completed. During the 10th Plan, five pontoons and mounted cranes and two shore cranes were also procured [7].

For encouraging states to develop IWT sector, funding pattern of CSS was revised in Nov 2002. In the revised pattern, $100 \%$ grant for NE States including Sikkim and $90 \%$ grant for other States was provided.

The Govt. approved an Inland Vessel Building Subsidy Scheme (IVBSS) under which 30\% subsidy was payable to the entrepreneurs for construction of inland vessels built in India for operation in national waterways, Sunderbans and Indo Bangladesh protocol routes. 
Table 7: Central Plan Outlay ad Expenditure during 2002-03 to 2006-07

Rs. in Lakhs

Year Central Schemes Centrally Sponsored

Total

Utilisation \%

Outlay Expenditure Outlay Expenditure Outlay Expenditure

\begin{tabular}{rrrrrrrl}
\hline $2002-03$ & 8690 & 7831 & 300 & Nil & 8990 & 7831 & 87.11 \\
$2003-04$ & 8868 & 8147 & 1000 & 985 & 9868 & 9132 & 92.54 \\
$2004-05$ & 12557 & 5796 & 2000 & 1598 & 14557 & 7394 & 50.79 \\
$2005-06$ & 13500 & 6551 & 1500 & 1500 & 15000 & 8051 & 53.67 \\
$2006-07$ & 13300 & 8839 & 1700 & 1200 & 15000 & 10039 & 66.93 \\
\hline Total & $\mathbf{5 6 9 1 5}$ & $\mathbf{3 7 1 6 4}$ & $\mathbf{6 5 0 0}$ & $\mathbf{5 2 8 3}$ & $\mathbf{6 3 4 1 5}$ & $\mathbf{4 2 4 4 7}$ & $\mathbf{6 6 . 9 4}$ \\
\hline
\end{tabular}

Source: Material supplied by TRW, M/0 Shipping

Table 7.1: State Plan Outlay and Expenditure during 2002-03 to 2006-07

\begin{tabular}{ccc} 
& \multicolumn{2}{c}{ Rs. In Lakhs } \\
\hline & \multicolumn{2}{c}{ State Plan } \\
\cline { 2 - 3 } & Outlay & Expenditure \\
\hline $2002-03$ & 19218 & 1434 \\
$2003-04$ & & 1340.88 \\
$2005-05$ & & 3096.31 \\
$2006-07$ & & 4773.48 \\
Total & & 1398.62 \\
\hline (\% Utilisation) & $\mathbf{( 1 0 2 1 8}$ & $\mathbf{1 2 0 4 3 . 2 9}$ \\
\hline
\end{tabular}

Source: Statistics of Inland Water Transport published by TRW, M/O Shipping 
Table 8:

(Rs. in Crore)

\begin{tabular}{cccc}
\hline Five Year Plan Outlay for Transport Sector & $\begin{array}{l}\text { Outlay } \\
\text { IWT }\end{array}$ & $\begin{array}{c}\text { for Expenditure } \\
\text { IWT }\end{array}$ & for \\
\hline 1st 1951-56 & 504 & 0 & 0 \\
2nd 1956-61 & 1299 & 0 & NA \\
3rd 1961-66 & 1395 & 6 & 11 \\
4th 1969-74 & 2571 & 12 & 16 \\
5th 1974-79 & 5420 & 32 & 63 \\
6th 1980-85 & 12080 & 72 & 188 \\
7th 1985-90 & 22644 & 226 & 152 \\
8th 1992-97 & 56090 & 331 & 147 \\
9th 1997-02 & 124188 & 308 & 384 (IWAI only) \\
10th 2002-07 & 148351 & 903 &
\end{tabular}

\section{1th FYP (2007-2012)}

The main developments during the Eleventh Plan were [32, 33]:

a) Two additional waterways were declared as National Waterways in November 2008. These were NW-4 and NW-5. As a result of this, the following waterways totalling 43, 82 $\mathrm{km}$ have been declared as National Water Ways (NWWs):

b) A major project was finalised involving a private agency for developing infrastructure and transportation of 3 million tonnes per year of imported coal from Sagar/Sandheads to Farakka power plant of NTPC Ltd. through NW-1 for a period of 7 years.

c) Pandu port in Guwahati was developed as an IWT based inter modal hub in the North East region with broad gauge railway connectivity.

d) Besides 8 terminals at various locations on NW-3, IWT Ro-Ro/Lo-Lo jetties at Bolghatty and Willingdon islands in Kochi on NW-3 were set up to provide IWT linkage to Vallarpadam Port.

e) Kaladan Multimodal Transport Project. This project was conceptualised by the Ministry of External Affairs to provide alternative connectivity from Mizoram to Haldia/Kolkata ports through River Kaladan in Myanmar. The project envisages Coastal Shipping/Maritime Shipping from Haldia to Sittwe, IWT from Sittwe to Paletwa (in Myanmar) and thereafter by road from Paletwa to Mizoram. 
Table 9: Financial performance during 11th FYP

\begin{tabular}{|r|l|r|r|r|r|r|r|}
\hline S. no. & Budget head/waterways & $\mathbf{2 0 0 7 - 0 8}$ & $\mathbf{2 0 0 8 - 0 9}$ & $\mathbf{2 0 0 9 - 1 0}$ & $\mathbf{2 0 1 0 - 1 1}$ & $\mathbf{2 0 1 1 - 1 2}$ & $\begin{array}{l}\text { Total 11th Plan } \\
\text { (Rs in cr.) }\end{array}$ \\
\hline & & Exp. & EXP & Exp & \multicolumn{1}{|c|}{ EXP } & EXP & EXP \\
\hline I & Grant to IWAI & & & & & & \\
\hline 1 & National waterway 1 & 41.85 & 52.77 & 38.75 & 49.59 & 45.99 & 228.95 \\
\hline 2 & National waterway 3 & 17.92 & 10.3 & 26.71 & 23.96 & 25.93 & 104.82 \\
\hline 3 & Others & 1.71 & 1.99 & 3.32 & 2.38 & 0.17 & 9.57 \\
\hline & Sub total (Grants to IWAI & $\mathbf{6 1 . 4 8}$ & $\mathbf{6 5 . 0 6}$ & $\mathbf{6 8 . 7 8}$ & $\mathbf{7 5 . 9 3}$ & $\mathbf{7 2 . 0 9}$ & $\mathbf{3 4 3 . 3 4}$ \\
\hline II & North Eastern Area & 19.47 & 32.18 & 55.1 & 37.51 & 57.81 & 202.07 \\
\hline 4 & National water way 2 & 0 & 0 & 1.05 & 3 & 2.57 & 6.62 \\
\hline 5 & Central Plan Scheme for NER@ & 0 & 0 & 0 & 0 & & 0 \\
\hline 6 & Proposed NW-6 (Barak) & $\mathbf{1 9 . 4 7}$ & $\mathbf{3 2 . 1 8}$ & $\mathbf{5 6 . 1 5}$ & $\mathbf{4 0 . 5 1}$ & $\mathbf{6 0 . 3 8}$ & $\mathbf{2 0 8 . 6 9}$ \\
\hline & Sub total II (NER) & 1.85 & 0.27 & 0 & 0.69 & 1.32 & 4.13 \\
\hline III & Subsidy & 1 & 0.82 & 1 & 0.5 & 1 & 4.32 \\
\hline IV & Tech Studies and R\&D & $\mathbf{8 3 . 8}$ & $\mathbf{9 8 . 3 3}$ & $\mathbf{1 2 5 . 9 3}$ & $\mathbf{1 7 7 . 6 3}$ & $\mathbf{1 3 4 . 7 9}$ & $\mathbf{5 6 0 . 4 8}$ \\
\hline & Grand Total & & & & & \\
\hline
\end{tabular}

POLICIES AND PROGRAMS TO ENCOURAGE IWT INDUSTRY

There are various initiatives and programs undertaken by Indian authorities to promote IWT. Following are the some of the major initiatives:

\section{Indo-Bangladesh Protocol on Inland Water Transit and Trade}

An Inland Water Transit and Trade Protocol exist between India and Bangladesh under which inland vessels of one country can transit through the specified inland water routes of other country. This protocol provides alternative connectivity of North East Region with Bangladesh as well as with rest of India through Haldia and Kolkata Port in West Bengal. The protocol was first signed in the year and has been extended after that. The Protocol is currently valid till March 2020[1].

This protocol connects National Waterway-1 (The Ganga River) with National Waterway-2 (The Brahmaputra River) and Barak river of Assam in North-East through designated inland water routes on Jamuna and Meghna river system of Bangladesh. The designated inland water routes under this protocol are (i) Kolkata-Silghat - Kolkata, (ii) Kolkata - Karimganj - Kolkata, (iii) Rajshahi - Dhulian, Rajshahi and (iv)Silghat - Karimganj - Silghat. For inter-country trade, five ports of call have been designated in each country. These are: Haldia, Kolkata, Pandu, Karimghat and Silghat in India and Narayanganj, Khulna, Mongla, Sirajganj and Ashuganj in Bangladesh.

Table 10: Details of cargo movement and voyage permissions

\begin{tabular}{|l|l|l|l|l|}
\hline \multirow{2}{*}{ Year } & Cargo moved & \multicolumn{2}{l|}{ Voyage permissions } \\
\cline { 2 - 5 } & (Lakh-Ton) & Inward & Outward & Total \\
\hline 2004 & 3.23 & 463 & 461 & 924 \\
\hline 2005 & 5.56 & 846 & 821 & 1,667 \\
\hline 2006 & 7.53 & 1,142 & 1,108 & 2,250 \\
\hline 2007 & 8.89 & 1,448 & 1,302 & 2,750 \\
\hline 2008 & 8.84 & 1,291 & 1,257 & 2,548 \\
\hline 2009 & 13.39 & 2,198 & 1,838 & 4,036 \\
\hline 2010 & 14.96 & 2,338 & 2,028 & 4,366 \\
\hline 2011 & 14.81 & 2,082 & 2,031 & 4,113 \\
\hline
\end{tabular}




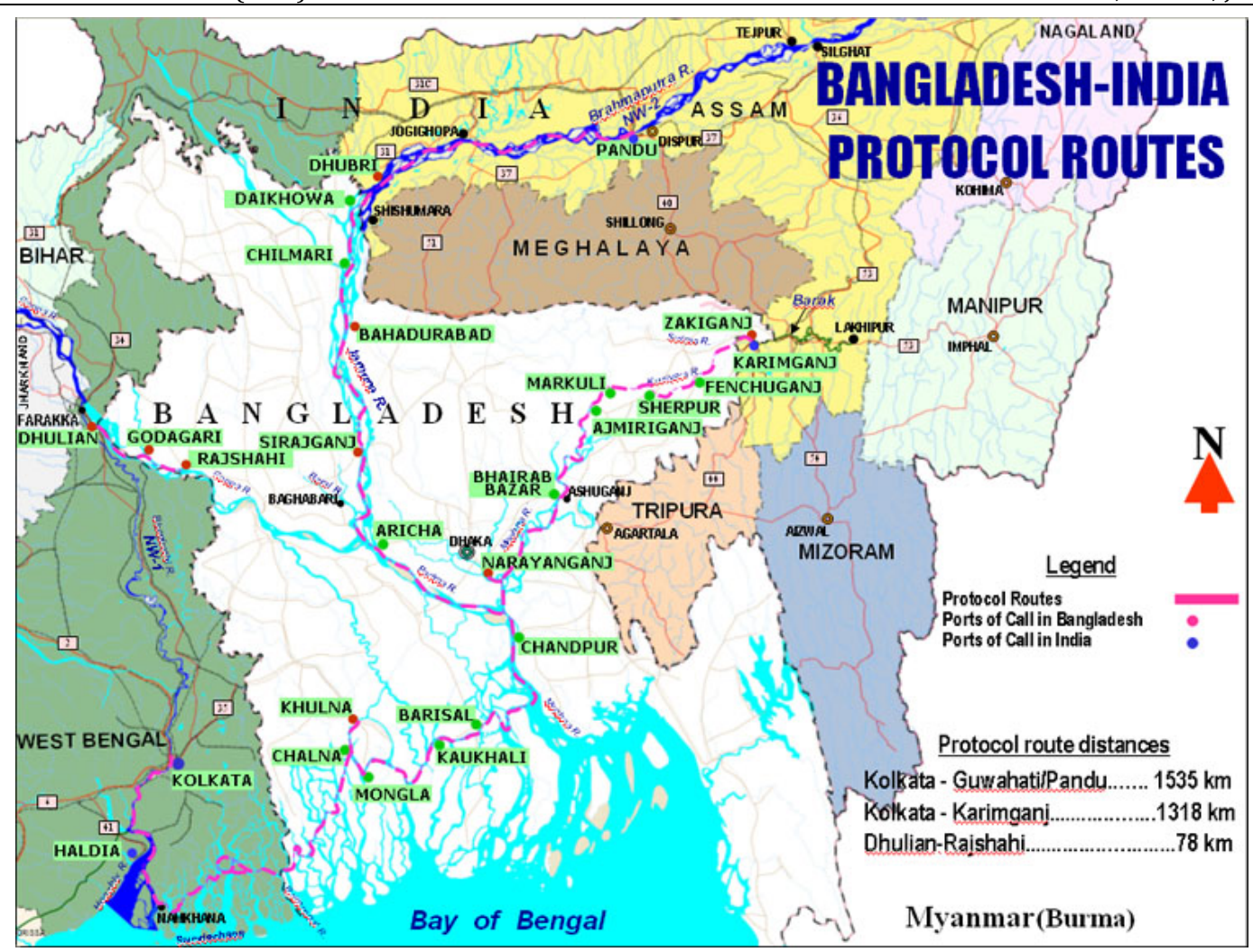

Figure 7: India Bangladesh Protocol Routes

\section{IWT Policy}

IWT Policy was announced by Government of India in year 2001. The policy recognises Inland Water Transport (IWT) is an economic, fuel-efficient and environment friendly mode of transport and need to actively promote the IWT sector for it to take a reasonable share in the inter-modal mix of inland transport. The policy includes several fiscal concessions, and policy guidelines for development of this mode and to encourage private sector participation in development of infrastructure and ownership and operation of inland vessels.

Following were identified as thrust areas in the policy for development of IWT [11]:

a) Developing waterways for navigation with the necessary infrastructure such as fairway, terminals, and navigational aids and fleet so that the IWT mode becomes competitive.

b) Augment the IWT fleet by suitable type of vessels and ensure adequate cargo support.

c) Encouraging private participation. The objective of developing IWT as an important mode of transport cannot be achieved only through the provision of budgetary support to the State enterprises. The private sector has to play a crucial role in the development of the sector.

d) Pooling PSU resources. Efforts will be made for pooling the resources through captive users such as public sector undertakings dealing with oil, coal, fertilisers and cement. These agencies will be encouraged to make liberal investment in IWT sector either as soft loan or as capital investment.

e) Funding from external sources. Another important avenue to be explored as a source of funding for the IWT projects would be the external resources. Investment in potential waterways as turn-key package with external assistance may be explored as part of privatisation.

f) Special emphasis would be laid on the development of inland water transport facilities in the North-Eastern region.

g) Developing human capital. Human resource development is also essential if the IWT objectives are to be achieved. For building up trained and skilled manpower for IWT 
operations, the setting up of a National Inland Navigation Institute, Regional Navigational Institutes and Regional Crew Training Centres was envisaged.

h) Interlinking waterways and ports with coastal shipping holds good prospects in respect of several river systems in India.

i) Research \& Development has to play a crucial role in the development on this sector. Design of low-cost and shallow-draft vessel and introduction of navigational aids are important factors for improving the economics of IWT.

\section{Encouraging Private Participation}

The policy provides initiatives, mechanisms and guidelines for private participation in IWT. The areas of private sector participation identified by Policy are listed below [11]:

a) Ownership and operation of vessels for cargo and passengers

b) Fairway development and maintenance

c) Construction and operation of river terminals or river ports

d) Provision and operation of mechanised cargo-handling systems

e) Putting up and maintenance of navigational aids

f) Provision of pilotage services

g) Setting up and running of IWT training institutions.

\section{Mechanism for Private participation}

a) The Government / IWAI will carry out a pre-feasibility study of the project identified for private investment and results of such studies would be provided to the prospective investors at a nominal cost and such details would be published in the National Newspapers for wide publicity.

b) A Detailed Project Report (DPR) will also be prepared by the IWAI which will form part of the tender document. Cost of the DPR study will be recovered from the successful bidder.

c) IWAI will also acquire the land wherever required for creation of facilities and hand over to the party on lease.

d) IWAI will assist the enterprise in obtaining environment clearance of the project.

e) Govt. support for facilitating long term cargo assurance.

Initiatives to encourage private participation [11]:

\section{Joint Venture by IWAI}

IWAI can enter into commercial/joint ventures subject to financial exposure of the Government being limited to equity participation. However, additional concessions in the form of grants, subsidies and other expenditure for development of infrastructure will not be within the scope of the joint venture projects.

\section{Equity participation by Govt. in BOT Projects}

Approval has been given for private sector participation subject to the equity participation of Government/IWAI Limited to ceiling of $40 \%$ for BOT project being worked out on case-to-case basis, subject to details of plan scheme for the purpose being finalized in consultation with Planning Commission. The details of some of the projects implemented under this scheme are as under: 
Table 11:

\begin{tabular}{|c|c|c|c|c|c|c|c|}
\hline $\begin{array}{l}\text { S. } \\
\text { no } \\
\text {. }\end{array}$ & $\begin{array}{l}\text { Com } \\
\text { pany } \\
\text { name }\end{array}$ & $\begin{array}{l}\text { Equity } \\
\text { particip } \\
\text { ation of }\end{array}$ & $\begin{array}{l}\text { Share } \\
\text { Holders } \\
\text { Agreement( } \\
\text { SHA) } \\
\end{array}$ & $\begin{array}{l}\text { Barrages } \\
\text { constructed }\end{array}$ & $\begin{array}{l}\text { Total } \\
\text { estimat } \\
\text { ed cost }\end{array}$ & $\begin{array}{l}\text { Equity } \\
\text { share \% }\end{array}$ & $\begin{array}{l}\text { Equit } \\
\text { y of } \\
\text { M/s } \\
\text { IWAI }\end{array}$ \\
\hline 1 & $\begin{array}{l}\text { Roya } \\
1 \\
\text { Logis } \\
\text { tics } \\
\text { (Ship } \\
\text { ) Ltd }\end{array}$ & $\begin{array}{l}\text { IWAI } \\
\text { and M/s } \\
\text { ad SK } \\
\text { logistics } \\
\text { LTD. }\end{array}$ & $\begin{array}{l}\text { Signed at } \\
\text { Noida on } \\
3.4 .08 \\
\text { between } \\
\text { IWAI and } \\
\text { M/s SKS } \\
\text { logistics } \\
\text { LTD. }\end{array}$ & $\begin{array}{l}\text { Six inland } \\
\text { barrages of } \\
2000 \text { DWT } \\
\text { each } \\
\text { constructed } \\
\text { and operated } \\
\text { between } \\
\text { Kolkata and } \\
\text { Pandu. }\end{array}$ & $\begin{array}{l}33.00 \\
\text { cr. }\end{array}$ & $\begin{array}{l}\text { M/s } \\
\text { SKS } \\
\text { Logistic } \\
\text { s Ltd - } \\
70 \%\end{array}$ & $30 \%$ \\
\hline 2 & $\begin{array}{l}\text { Viva } \\
\text { da } \\
\text { Logis } \\
\text { tics } \\
\text { Pvt. } \\
\text { Ltd }\end{array}$ & $\begin{array}{l}\text { IWAI } \\
\text { and M/s } \\
\text { Vivada } \\
\text { and } \\
\text { Inland } \\
\text { waterwa } \\
\text { y LTD. }\end{array}$ & $\begin{array}{l}\text { SHA for this } \\
\text { company } \\
\text { was signed } \\
\text { at Noida on } \\
\text { 13.5.08. }\end{array}$ & $\begin{array}{l}\text { Two inland } \\
\text { barrages of } \\
1500 \text { DWT } \\
\text { each are } \\
\text { envisaged } \\
\text { to be } \\
\text { constructed } \\
\text { and operated }\end{array}$ & $\begin{array}{l}10.00 \\
\text { cr. }\end{array}$ & $\begin{array}{l}\mathrm{M} / \mathrm{s} \\
\text { Vivada } \\
\text { Inland } \\
\text { Waterw } \\
\text { ays - } \\
70 \%\end{array}$ & $30 \%$ \\
\hline 3 & $\begin{array}{l}\text { SKS } \\
\text { Wate } \\
\text { rway } \\
\text { s Ltd }\end{array}$ & $\begin{array}{l}\text { IWAI } \\
\text { and M/s } \\
\text { ad SK } \\
\text { logistics } \\
\text { LTD. }\end{array}$ & $\begin{array}{l}\text { SHA for this } \\
\text { company } \\
\text { was signed } \\
\text { at Noida on } \\
12.6 .08 \\
\text { between } \\
\text { IWAI and } \\
\text { M/s SKS } \\
\text { Logistics } \\
\text { Ltd. }\end{array}$ & $\begin{array}{l}\text { Eight inland } \\
\text { barrages of } \\
2000 \text { DWT } \\
\text { each } \\
\text { constructed } \\
\text { and operated } \\
\text { between } \\
\text { Kolkata and } \\
\text { Mongla } \\
\text { (Bangladesh } \\
\text { ). }\end{array}$ & $\begin{array}{l}44.00 \\
\text { cr. }\end{array}$ & $\begin{array}{l}\mathrm{M} / \mathrm{s} \\
\text { SKS } \\
\text { Logistic } \\
\text { S Ltd - } \\
70 \%\end{array}$ & $30 \%$ \\
\hline 4 & IWAI & $\begin{array}{l}\text { M/s ICM } \\
\text { (I) Pvt. } \\
\text { Ltd., } \\
\text { Kolkata. }\end{array}$ & & $\begin{array}{l}\text { Setting up } \\
\text { and } \\
\text { operation on } \\
3 \text { floating } \\
\text { jetties in } \\
\text { West Bengal } \\
\text { for handling } \\
\text { of flyash } \\
\text { being export } \\
\text { to } \\
\text { Bangladesh. }\end{array}$ & $2.70 \mathrm{cr}$ & $\begin{array}{l}\mathrm{M} / \mathrm{s} \\
\mathrm{ICM} \quad(\mathrm{I}) \\
\text { Pvt. Ltd. } \\
-90 \% .\end{array}$ & $10 \%$ \\
\hline
\end{tabular}

\section{Tax exemption similar to National Highways}

Grant of $100 \%$ tax exemption to investors in this sector for five years and further $30 \%$ tax exemption permissible under the Income Tax Act to be availed of in the next five years within a period of 15 years as in the case of National Highways so as to enable this sector to develop. 


\section{Enhancement in depreciation rate for inland vessels}

The rate of depreciation for all vessels ordinarily operating on Inland Waterways will be fixed on a par with the rate of depreciation applicable to ocean going vessels, from time to time.

\section{Vessel Building Subsidy of $30 \%$}

With a view to encouraging IWT fleet expansion, a scheme will be operationalized providing for vessel building subsidy of $30 \%$ for ship owners for inland vessels built in Indian shipyards during Ninth FYP. This subsidy was only provided during tenth FYP and discontinued thereafter. Several representations have been made to Government to restart this subsidy.

\section{Customs Duty concessions.}

In-principle approval has been given for levying minimum customs duty on imported equipment and machinery for the development of inland waterways to be identified by IWAI. A list of such equipment/machinery items will be submitted by the Ministry of Shipping to the Ministry of Finance in advance so as to facilitate levying of minimum custom duty.

\section{TAX / FISCAL CONCESSIONS}

Concession under Section-33 and 33 AC of the IT Act 1986 to be applicable to the inland vessels as applicable to the sea going ships. Rate of depreciation of $25 \%$ applicable for inland vessels at par with sea going ships. Concessions under Section 80 IA-12(CA) of the IT Act 1996 would be available for investment in IWT infrastructure. Govt. would permit duty free import of plants, equipment and machinery for development of inland waterways. (Certification to be provided by IWAI).

\section{FOREIGN INVESTMENT}

Government has decided to permit automatically Foreign Direct Investment upto 100\% equity for infrastructure sector. This would be applicable to IWT infrastructure.

\section{Central Sector Scheme (CSS)}

This scheme has been launched for the development of IWT infrastructure in the States of North East India. Under this scheme provision for $100 \%$ subsidy is being provided by the Ministry of Shipping for development of Inland Water transport projects in North East States of the Country [34]. These projects are executed by respective State Governments. 
Table 12: Projects are under progress in NER

\begin{tabular}{|c|c|c|c|}
\hline $\begin{array}{l}\text { SI. } \\
\text { No }\end{array}$ & Project & $\begin{array}{l}\text { Project cost } \\
\text { (Rs. In Cr) }\end{array}$ & Status \\
\hline 1 & $\begin{array}{l}\text { Assam } \\
\text { Construction of } 20 \text { floating } \\
\text { terminals along the } \\
\text { Brahmaputra }\end{array}$ & 4.5 & $\begin{array}{l}\text { Project completed in } \\
2014\end{array}$ \\
\hline 2 & $\begin{array}{l}\text { Construction of } 15 \text { floating } \\
\text { terminals along the } \\
\text { Brahmaputra }\end{array}$ & 6.07 & $\begin{array}{l}\text { Project sanctioned in } \\
2014 \text { and scheduled to } \\
\text { be completed in } 2016\end{array}$ \\
\hline 3 & $\begin{array}{l}\text { Mizoram } \\
\begin{array}{l}\text { Development } \\
\text { river for IWT }\end{array} \text { of Tlawng } \\
\end{array}$ & 5.28 & $\begin{array}{l}\text { Project completed in } \\
2013\end{array}$ \\
\hline 4 & $\begin{array}{l}\text { Tripura } \\
\text { DPRs for development of } \\
\text { IWT in Gumti \& Haora } \\
\text { rivers }\end{array}$ & 0.83 & $\begin{array}{l}\text { Project completed in } \\
\text { April } 2015\end{array}$ \\
\hline 5 & $\begin{array}{l}\text { Development of IWT in } \\
\text { Gumti river as per DPR }\end{array}$ & 12.59 & $\begin{array}{l}\text { Project recommended } \\
\text { and under consideration } \\
\text { in Ministry of Shipping }\end{array}$ \\
\hline & Manipur & & Project submitted on \\
\hline 6 & $\begin{array}{l}\text { Development of Loktak } \\
\text { lake for IWT }\end{array}$ & 14.29 & $\begin{array}{l}31.08 .15 . \\
\text { held with Secretary } \\
\text { (Transport),Manipur on } \\
\text { 10.09.15, they will } \\
\text { revise the project. }\end{array}$ \\
\hline
\end{tabular}

Source: IWAI presentation (2015), Importance of Inland Water Transport for North East, FICCI Summit, Shillong [35]

\section{Jal Vikas Marg Project}

The 'Jal Marg Vikas' (National Waterway-1) project envisages to develop a fairway with 3 meters depth between Allahabad to Haldia covering a distance of $1620 \mathrm{kms}$ at an estimated cost of Rs. 4200 crore to be completed in six years from 2014-2020. This would enable commercial navigation of at least 1500 ton vessels. Construction of multi modal terminals, jetties, river information system, channel marking, navigational lock, river training and conservancy works are to be undertaken as part of the project. The project is being implemented with technical and investment support from World Bank [36].

The following are the key projects undertaken under Jal Vikas Marg Project [1]

a) Jal Marg Vikas Project for capacity augmentation of navigation on National Waterways I (Allahabad - Haldia stretch) with Least Availability Depth (LAD) of up to 3.0 meter for commercial navigation

b) Construction of Multimodal terminal at Haldia, Varanasi, Sahibganj

c) Construction of new navigational lock at Farakka.

d) Least Assured Depth on Farakka-Kahalgaon Stretch

\section{Ro-Ro Barge service}

International Container Transhipment Terminal (ICTT) has been commissioned on year 2011 at Vallarpadam Island under Cochin Port Trust (CPT). IWAI in collaboration with CPT has established two IWT terminals at Bolgatty and Willingdon Island for feeding containers to ICTT 
at Vallarpadam and to reduce the congestion on road traffic in Cochin City [37]. RORO services are also being implemented at various points in NW2 [1].

\section{Kaladan Multi-modal Transit Transport Project}

The Kaladan Multi-Modal Transit Transport Project is a project that will connect the eastern Indian seaport of Kolkata with Sittwe seaport in Myanmar by sea; it will then link Sittwe seaport to Paletwa in Myanmar via Kaladan river boat route and then from Paletwa on to Mizoram by road transport [38].

The main objective of the project is to provide alternate connectivity to North Eastern India from mainland India. This project will reduce the need to transport good through the narrow Siliguri corridor, also known as Chicken's Neck.

The project is being piloted and funded by the Ministry of External Affairs (India). The preliminary feasibility studies were carried out by Rail India Technical and Economic Services (RITES).

\section{Skill Development}

Indian Government recognizes that trained and skilled manpower are essential for IWT operations. Trained manpower in the IWT sector is required in various fields, like hydrography, navigation, civil engineering, mechanical engineering, naval architecture and transport economics for the development and management of the waterways and operation of various supporting infrastructural facilities [11]. Accordingly The National Inland Navigation Institute (NINI) has been set up by Inland Waterways Authority of India (IWAI) at Patna, Bihar in February 2004 with a view to develop human resource for the Inland Water Transport sector including development, maintenance and management of waterways. The institute imparts quality training on various aspects of inland water transportation namely development \& management of waterways, surveying \& dredging of waterways, design \& construction of terminals, design \& construction of vessels, Technical \& commercial operation of vessels, running of vessels, terminal management, and traffic management. The institute provides refresher and upgradation education to existing professionals in river engineering, dredging, surveying, Hydrography, repair \& maintenance of inland vessels [18].

\section{Creation of logistic hubs with rail connectivity}

A Memorandum of Understanding (MoU) was signed in 2015 between the Inland Waterways Authority of India (IWAI) and the Dedicated Freight Corridor Corporation of India (DFCCIL) for creation of logistic hubs with rail connectivity at Varanasi and other places on National Waterways [39]. The joint development of state-of-the-art logistics hubs at Varanasi and other places would lead to convergence of inland waterways with rail and road connectivity. This would provide a seamless, efficient and cost effective cargo transportation solution particularly for containers [39].

\section{Creation of new 106 National Waterways}

Indian Parliament in March 2016 gave a nod to a bill to convert 106 rivers across the country into National Waterways. The bill provides for enacting a central legislation to declare 106 additional inland waterways as the national waterways in addition to five existing national waterways [20]. 


\section{Integrated National Inland Waterways Transport Grid (INWTG)}

IWAI engaged RITES Ltd (earlier known as Rail India Technical and Economic Service, is an engineering consultancy company, specializing in the field of transport infrastructure) to conduct detail study on creation of a transportation Grid to connect various important Waterways to important Highways and Railways to boost the overall transportation network in the country. INWTG identified 27 terminals on NW1 to 6 to develop this grid and the nearest Railhead and National/State Highway to build connectivity. The report also suggested infrastructure development costs for fairway development, Terminal construction and establishing Rail and Road connectivity [40]. Based on the outcome of the study a Cabinet Note to undertake and implement the project for setting up of Integrated National Waterways Transportation Grid was prepared and an EFC Note for the proposal has been circulated among the concerned Ministries for their concurrence [1].

\section{Incentive Scheme for Modal shift}

Ministry of Shipping has launched a Scheme called "Scheme for Incentivizing Modal Shift of Cargo" or "SIMSC" [41] [42]. The Scheme broadly covers the following:-

The incentives under SIMSC will be provided to the beneficiaries for undertaking transportation of the following categories of cargo through Indian flag vessels, River Sea Vessels or barges on coastal shipping and inland waterways routes, namely:-

1. Transportation of bulk or break - bulk cargo pertaining to seven commodities viz. Fertilizers, food grains, marbles, tiles, sugar, edible salt and over - dimensional cargo, shall be eligible for an incentive @ Re. 1 per tonne per nautical mile upto a maximum of 1,500 nautical miles in each trip starting from origin and ending at the destination. The number and type of commodities under this head are subject to revision by the Government from time-to-time.

2. Transportation of any commodity in containers in Full Container Load (FCL) shall be eligible for an incentive @ Rs.3000/- per TEU. Thus transportation of any commodity through forty feet or other larger sized containers shall be incentivised based on number of times the said container size can be converted into TEUs.

3. Transportation of vehicles through Ro-Ro Vessels shall be eligible for the following incentives:

a) Incentive @ Rs. 300/-per two-wheeler vehicle;

b) Incentive @600/-per three-wheeler vehicle; and

c) Incentive @ Rs.3000/- for other vehicles.

\section{A COMPARISON OF INDIAN IWT WITH US, EU AND CHINA}

The following table provides a brief comparison of IWT progress in India with US, EU and China $[43,1]$ 
Table 13

\begin{tabular}{|c|c|c|c|c|}
\hline & US & $\mathbf{E U}$ & China & India \\
\hline $\begin{array}{l}\text { Waterw } \\
\text { ays } \\
\text { Length } \\
\text { in KMs }\end{array}$ & $\begin{array}{l}\text { Designated } \\
\text { Waterways } \\
40,000 ; \\
\text { Commercially } \\
\text { Significant } \\
16,000\end{array}$ & $\begin{array}{l}\text { Designated } \\
\text { Waterways } \\
35,000 ; \\
\text { Commercially } \\
\text { Significant - } \\
8,000\end{array}$ & $\begin{array}{l}\text { Designated } \\
\text { Waterways } \\
61,000 ; \\
\text { Commercially } \\
\text { Significant - } \\
24,000\end{array}$ & $\begin{array}{l}\text { Designated } \\
\text { Waterways - } \\
4,400 ; \\
\text { Commercially } \\
\text { Significant - } \\
2,900^{*}\end{array}$ \\
\hline $\begin{array}{l}\text { Freight } \\
\text { Utilizati } \\
\text { on in } \\
\text { Million } \\
\text { MT and } \\
\text { Billion } \\
\text { Ton KM }\end{array}$ & $\begin{array}{l}566,400 \text { ( Year } \\
2005)\end{array}$ & $\begin{array}{l}440,138 \text { ( Year } \\
2006)\end{array}$ & $\begin{array}{l}1160,303 \\
\text { Year 2006) }\end{array}$ & $\begin{array}{l}70,4.77 \text { ( Year } \\
\text { 2011-12) }\end{array}$ \\
\hline $\begin{array}{l}\text { IWT } \\
\text { share on } \\
\text { total } \\
\text { Ton KM }\end{array}$ & $8.30 \%$ & $5.60 \%$ & $8.70 \%$ & $<0.5 \%$ \\
\hline $\begin{array}{l}\text { Main } \\
\text { Commo } \\
\text { dity } \\
\text { Types } \\
\text { Using } \\
\text { IWT }\end{array}$ & $\begin{array}{l}\text { Coal \& } \text { coke } \\
22 \% \\
\text { Oil and oil } \\
\text { prods. } 14 \% \\
\text { Food, grains, } \\
\text { farm } 25 \% \quad( \\
\text { Year } 2005) \\
\text { Crude materials } \\
18 \% \\
\text { Chemicals } 11 \% \\
\text { Manufactures } \\
9 \% \\
\text { Others } 1 \%\end{array}$ & $\begin{array}{lr}\text { Coal \& } & \text { coke } \\
11.6 \% & \\
\text { Oil \& } & \text { oil } \\
\text { products } & 16.2 \% \\
\text { Agriculture \& \& } \\
\text { food } 14.6 \% \quad( \\
\text { Year } 2005) \\
\text { Building } \\
\text { materials } & \\
\text { Chemical } & \text { and } \\
\text { fertilizers } & \\
11.1 \% & \\
\text { Manufact. } & \text { \& } \\
\text { Iron/steel } & \\
16.6 \% & \end{array}$ & $\begin{array}{lr}\text { Coal \& } & \text { coke } \\
17 \% & \\
\text { Oil \& } & \text { oil } \\
\text { products } & 8 \% \\
\text { Metallic } & \& \\
\text { non-met. } & \text { ores } \\
19 \% \quad(\quad \text { Year } \\
2006) \\
\text { Building } \\
\text { materials } & 34 \% \# \\
\text { Steel } & 7 \% \\
\text { Containers } & 6 \% \\
\text { Others } 9 \% & \end{array}$ & $\begin{array}{l}\text { Coal, cement, } \\
\text { bauxite, iron } \\
\text { ore pellets, } \\
\text { stone, HR } \\
\text { steel, project } \\
\text { cargo } \\
\text { and related raw } \\
\text { material, } \\
\text { Sulphur, rock } \\
\text { phosphate, } \\
\text { cement, lime } \\
\text { stone } \\
\& \text { clinker }( \\
\text { Year 2011-12) }\end{array}$ \\
\hline $\begin{array}{l}\text { Contain } \\
\text { ers } \\
\text { handled } \\
\text { at } \\
\text { inland } \\
\text { ports }\end{array}$ & Negligible & $\begin{array}{l}\text { About } 2 \text { million } \\
\text { TEU trips/year } \\
(2005)\end{array}$ & $\begin{array}{l}7.82 \text { million } \\
\text { TEU } \\
\text { handled/year } \\
(2006)\end{array}$ & Negligible \\
\hline
\end{tabular}




\begin{tabular}{|c|c|c|c|c|}
\hline $\begin{array}{l}\text { Main } \\
\text { Policy } \\
\text { and } \\
\text { Adminis } \\
\text { trative } \\
\text { Instituti } \\
\text { ons in } \\
\text { IWT } \\
\text { Sector }\end{array}$ & $\begin{array}{l}\text { 1. Maritime } \\
\text { Administration } \\
\text { of the } \\
\text { US Department } \\
\text { of } \\
\text { Transportation } \\
\text { (MARAD) } \\
2 \text { US Army } \\
\text { Corps of } \\
\text { Engineers } \\
\text { (USACE) }\end{array}$ & $\begin{array}{l}\text { European } \\
\text { Union } \\
1 \text { River } \\
\text { Commissions } \\
\text { set up by } \\
\text { international } \\
\text { treaty } \\
2 \quad \text { National } \\
\text { Governments } \\
3 \text { United } \\
\text { Nations } \\
\text { Economic } \\
\text { Commission } \\
\text { for Europe } \\
\text { (UNECE) } \\
\text { (harmonization } \\
\text { of pan- } \\
\text { European } \\
\text { navigation } \\
\text { rules) }\end{array}$ & $\begin{array}{l}1 \text { Ministry of } \\
\text { Water } \\
\text { Resources } \\
2 \text { Ministry of } \\
\text { Transport } \\
\text { (MOT) } \\
3 \text { Yangtze and } \\
\text { Pearl River } \\
\text { Navigation } \\
\text { administrations } \\
\text { (report to } \\
\text { MOT) Provincial } \\
4 \text { Pornents } \\
\text { Government } \\
\text { and navigation } \\
\text { authorities. }\end{array}$ & $\begin{array}{l}\text { 1. Ministry of } \\
\text { Shipping } \\
2 . \quad \text { Inland } \\
\text { Waterways } \\
\text { Authority of } \\
\text { India }\end{array}$ \\
\hline $\begin{array}{l}\text { Strategi } \\
\text { c } \\
\text { objectiv } \\
\text { es. }\end{array}$ & 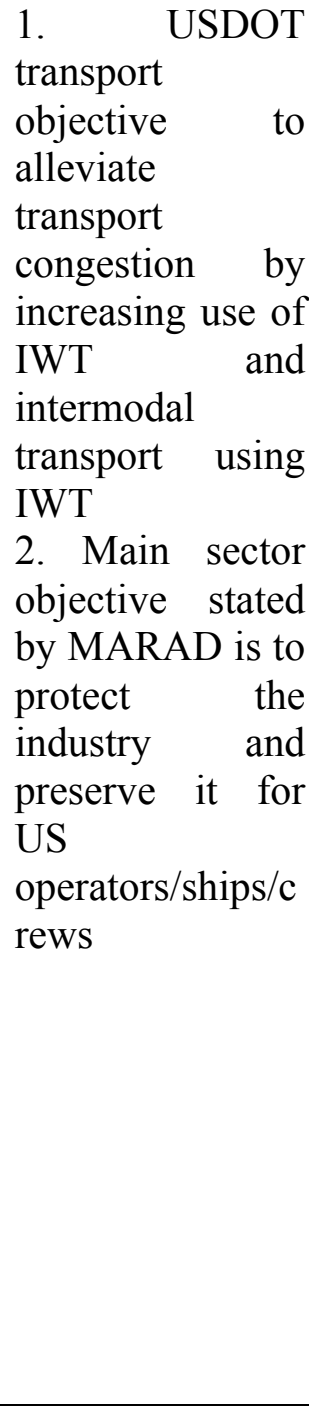 & $\begin{array}{l}\text { 1. To promote } \\
\text { and strengthen } \\
\text { the competitive } \\
\text { position of } \\
\text { IWT to help } \\
\text { create a more } \\
\text { sustainable } \\
\text { transport } \\
\text { system overall } \\
\text { 2. To overcome } \\
\text { bottlenecks and } \\
\text { increase } \\
\text { connectivity of } \\
\text { waterways of } \\
\text { EU-wide } \\
\text { significance }\end{array}$ & $\begin{array}{l}\text { 1. To increase } \\
\text { the utilization } \\
\text { of IWT by } \\
\text { substantially } \\
\text { upgrading the } \\
\text { waterway } \\
\text { system } \\
2020 \text { : } \\
\text {-increase Class } \\
\text { III+ from } \\
8,687 \mathrm{~km} \text { to } \\
14,300 \mathrm{~km} \text {-increase Class } \\
\text { V+ from } \\
\text { 24,000 to } \\
36,000 \\
2 . \text { To promote a } \\
\text { more efficient } \\
\text { and effective } \\
\text { fleet of vessels }\end{array}$ & $\begin{array}{l}\text { Vision: The } \\
\text { vision/objective } \\
\text { of development } \\
\text { of inland } \\
\text { waterways of the } \\
\text { country is their } \\
\text { increased } \\
\text { utilization for } \\
\text { transportation of } \\
\text { cargo to about } \\
20 \text { billion tonne } \\
\text { km by } 2020 . \\
\text { Mission : To } \\
\text { develop all } \\
\text { potential inland } \\
\text { waterways with } \\
\text { adequate IWT } \\
\text { infrastructure } \\
\text { both through } \\
\text { public and } \\
\text { private funding } \\
\text { to make them a } \\
\text { commercially } \\
\text { viable mode for } \\
\text { transportation of } \\
\text { goods to act as } \\
\text { supplementary } \\
\text { mode of } \\
\text { transport with } \\
\text { respect to rail } \\
\text { and road modes } \\
\text { [44] }\end{array}$ \\
\hline
\end{tabular}




\begin{tabular}{|c|c|c|c|c|}
\hline $\begin{array}{l}\text { Progra } \\
\text { ms } \\
\text { being } \\
\text { run }\end{array}$ & $\begin{array}{lr}1 . & \text { USDOT } \\
\text { Strategic Plan } \\
2005-2011 \text { and } \\
\text { MARAD } \\
\text { Strategy 2003- } \\
2008 \\
2 . \text { Coastal and } \\
\text { River } \\
\text { Information } \\
\text { Services } \\
\text { development and } \\
\text { implementation } \\
\text { (CRIS) }\end{array}$ & $\begin{array}{l}\text { 1. National } \\
\text { programs, plus } \\
2 . \quad \text { Navigation } \\
\text { and Inland } \\
\text { Waterway } \\
\text { Action and } \\
\text { Development } \\
\text { Plan in Europe } \\
\text { (NAIADES) } \\
\text { 3. Marco Polo } \\
\text { Program } \\
\text { Trans European } \\
\text { Network } \\
\text { program (TEN- } \\
\text { T) : } 2 \text { IWT } \\
\text { projects } \\
4 . \text { Harmonized } \\
\text { River } \\
\text { Information } \\
\text { Services (RIS) }\end{array}$ & $\begin{array}{l}\text { Long-term } \\
\text { Waterway } \\
\text { 1. Development } \\
\text { Plan to } 2020 \\
2 . \quad 11 \text { th } 5 \text {-year } \\
\text { plan to } 2010 \\
3 . \quad \text { Vessel } \\
\text { standardization } \\
\text { program } \\
4 . \quad \text { Early } \\
\text { framework } \\
\text { design for an } \\
\text { integrated river } \\
\text { information } \\
\text { service }\end{array}$ & $\begin{array}{l}\text { 1. IWT Policy } \\
\text { 2. Indo } \\
\text { Bangladesh } \\
\text { Protocol } \\
\text { 3. Kaladan } \\
\text { Multi-modal } \\
\text { Transit } \\
\text { Transport } \\
\text { Project } \\
\text { 4. Integrated } \\
\text { National Inland } \\
\text { Waterways } \\
\text { Transport Grid } \\
\text { (INWTG) } \\
\text { 5. Jal Vikas } \\
\text { Marg Project }\end{array}$ \\
\hline
\end{tabular}

* Sum of NW1,2,3 and Goa and Mumbai Waterways

\section{BARRIERS AND CHALLENGES TO GROWTH OF IWT}

In spite of carrying so many advantages, the development of IWT has been unsatisfactory in India. Following are the key reasons which have been impeding the growth

Natural Barriers: River is a natural medium. There are some nature related constraints which limit the use of rivers for navigation in India:

a) Geography of India: There are no very large rivers in India which flow across length and breadth of the country. Like Yangtze in China which flows a very large distance across the length of the country covering many provinces. Most of the Indian rivers are locational, cover small geography and undergo huge seasonal fluctuations rendering them unsuitable for navigation.

b) Alluvial nature of rivers: Ganga and Brahmaputra, the two largest rivers in India are alluvial in nature. They bring large amount of siltation with them and need to be continuously dredged to allow navigation [45].

\section{Policy and Regulatory}

a) Priority of IWT: In water resources development agenda of India, navigation is relegated at the end after issues of drinking water, irrigation and power (hydel) sector [46]. This is perhaps the single biggest reason for lack of development of IWT in India. Water is a scarce resource in India. It has to first meet the basic requirements before it can be used for navigation. The rivers are dammed for water to be first used for drinking and irrigation before it can be used for any other purpose [47]. There were no long term visions for development of IWT which lead to building of dams without locks, bridges without adequate clearances for barges to move. Retro fitting these things are turning about to be almost impossible tasks for the Government.

b) Poor fund allocation: Lack of priority for IWT is also reflected by poor allocation of funds for this sector. The following table indicates the funds allocated for the sector. This is meagre compared to other developing countries like China. IWT never enjoyed 
funding anywhere close to that allocated to Railways or Road. The most unfortunate part is that the funds allocated are also not completely used every year.

Table 14 : Year wise Expenditure on National Waterways by IWAI

\begin{tabular}{|c|c|c|c|c|}
\hline \multirow[t]{2}{*}{ YEAR } & \multicolumn{4}{|c|}{$\begin{array}{l}\text { EXPENDITURE (INR in Crore (Ten } \\
\text { million)) }\end{array}$} \\
\hline & NW-1 & NW-2 & NW-3 & TOTAL \\
\hline 1986-87 & 1.67 & & & \\
\hline $1987-88$ & 1.34 & & & \\
\hline 1988-89 & 2.83 & & & \\
\hline $1989-90$ & 1.21 & 0.56 & & \\
\hline 1990-91 & 1.44 & 1.04 & & \\
\hline 1991-92 & 2.59 & 1.81 & & \\
\hline $1992-93$ & \multirow{5}{*}{10.58} & \multirow{5}{*}{4.22} & & \\
\hline 1993-94 & & & & \\
\hline 1994-95 & & & 1.43 & \\
\hline $1995-96$ & & & 1.1 & \\
\hline 1996-97 & & & 7.93 & \\
\hline $1997-98$ & 6.47 & 2.59 & 8.75 & \\
\hline 1998-99 & 11.8 & 5.83 & 9.62 & \\
\hline $1999-2000$ & 7.91 & 3.22 & 12.9 & \\
\hline 2000-01 & 16.11 & 5.26 & 1.77 & \\
\hline 2001-02 & 17.6 & 8.79 & 7.27 & \\
\hline $2002-03$ & 23.52 & 15.43 & 2.31 & \\
\hline 2003-04 & 31.36 & 20.7 & 5.77 & \\
\hline 2004-05 & 13.74 & 24.8 & 7.69 & \\
\hline $2005-06$ & 24.76 & 35.61 & 4.86 & \\
\hline 2006-07 & 42.24 & 35.61 & 10.35 & \\
\hline 2007-08 & 41.85 & 19.47 & 17.92 & \\
\hline 2008-09 & 52.77 & 32.18 & 10.3 & \\
\hline 2009-10 & 38.75 & 55.1 & 26.71 & \\
\hline $2010-11$ & 49.59 & 37.51 & 21.62 & \\
\hline 2011-12 & 45.98 & 57.51 & 25.93 & \\
\hline $2012-13$ & 58.89 & 45.05 & 20.59 & \\
\hline 2013-14 & 48.74 & 51.45 & 21.25 & \\
\hline 2014-15 & 62.58 & 40.68 & 10.35 & \\
\hline 2015-16 (Dec 15) & & & 3.84 & \\
\hline TOTAL & 616.32 & 504.42 & 240.26 & 1361 \\
\hline
\end{tabular}

c) Lack of industrializatic. Lack of Industrialisation on river banks: Studies emphasise that the geographical advantage that IWT possesses is strongest if the entire movement is on a river [12]. In other words, this mode is most attractive for a river based project activity [2]. In China Industrial parks have been developed along the river banks [43]. However, in India no such planning had been done and there are hardly manufacturing hubs close to river banks. 
d) Lack of Private participation: There are many potential areas where private sector can participate in IWT. Terminal and warehousing facilities, mechanization of the cargohandling system, installation of the new navigational aids, deploying low draft barges and vessels and maintenance of the existing fairways [11]. Varieties of possible Public-Private-Participation framework have been deployed by the Government. However the private participation has been lukewarm till date. The private sector still does not see the expected return on investment in IWT sector. Some of the policy initiatives have been inconsistent like withdrawing the vessel capital subsidy after 5 years.

e) Governance structure in India: The structure consists of Ministry of Shipping under whom IWAI is responsible for development of IWT mode. The participation from State governments is meagre. The entire onus is on IWAI only. In Europe there is separate Rhine and Danube River Commissions, in China there are Yangtze and Pearl River Navigation Administration. These are bodies which are responsible for development of the rivers under their jurisdiction. In India no separate bodies were created for managing Ganga or Brahmaputra. With 5 earlier NW and new 106 NW to be developed, IWAI has its hands full.

\section{Technical Challenges}

a) Lack of LAD: Another very large reason for poor development of IWT in India has been inability to offer a consistent LAD of $2.5 \mathrm{~m}$ to $3 \mathrm{~m}$ round the year [48]. Even after 30 years of declaration of NW1, IWAI is still not able to provide a consistent depth of 2.5 to $3 \mathrm{~m}$ on NW1. The stretch from Allahabad to Patna still remains a challenge to the Government.

b) Navigational Aids: Lack of navigational aids does not allow 24 hours navigation and round the year movement. IWT is a slower mode as compared by Rail and Road by its very nature. Improper navigational aids further hurt its competitiveness vis-à-vis other modes [49].

c) Terminals: IWT is not an independent mode like Road. It needs Road to provide first mile and last mile connectivity. Non-availability of permanent terminals with adequate infrastructure for loading / unloading and storage is another impeding factor. (s) Most of the terminals in India are still floating terminals. Very few of them are permanent in nature. Further there is lack of mechanised handling at terminals [49]. Very few terminals are truly intermodal. Government has neither been able to encourage private participation nor able to rope in agencies like CONCOR to manage terminals.

d) Barges and Vessels: Unavailability of low draft high technology vessels is another limiting factor which is perhaps hurting the most 2]. There are shortage of IWT vessels as this is highly capital intensive and faces difficulties in obtaining Project Final from Banks/FIIs since it does not enjoy "infrastructure" status currently. With lack of adequate cargo and two way loads the vessels buying is not turning out to be a profitable venture for any Bank to lend.

e) MRO: Maintenance, Repair and Overhaul facilities are very poor at IWT terminal and hence lot of time and money is wasted in taking the vessels for repair up to the main port. There is no MRO facility on NW2.

f) Inadequate Air draft: There are road and rail bridges with low vertical clearance which impede passage of bigger IWT vessels on the waterways [2].

g) RIS system: The government did deploy state of the art RIS system. However till date it has not been implemented across all NWs. It is still operating in parts of NW1. 


\section{FUTURE DIRECTIONS AND RECOMMENDATIONS}

The authors would like to make following recommendations to increase the share of IWT in India:

a) Focused Approach: The Indian Government should focus all its efforts and funds on development of "commercially significant" waterways. We have not been able to fully operationalize five declared waterways, declaration and development of another 106 waterways will further dilute IWAI attention. NW1 is the most important waterway and need to be strongly focused followed by NW2 and NW5.

b) LAD of 3m: IWT as a mode will not commercial sense unless we ply more than 1000 DWT vessels. This requires a minimum LAD of 2.5 to $3 \mathrm{~m}$ round the year with night navigation facilities. IWAI should spend funds and make all possible efforts to train Ganga and Brahmaputra River to achieve desired LAD.

c) Governance Structure: The way NHAI (National Highway Authority of India) is responsible for development of National Highways and State Govt for State Highways and other roads, similarly IWAI should be responsible only for development of National Waterways and State Govt for other state waterways. This will help to develop feeder routes and help create "fish bone model". Currently State Govts hardly participate in the development of IWT. Govt may also consider creating a separate commission for rivers Ganga and Brahmaputra. This commission would be responsible for overall management of the river. The commission will be responsible for holistic development of the river integrating various uses like drinking water, irrigation, hydel power, fishing, tourism and navigation.

d) Intermodality: IWT being a dependent mode, there is a strong need to provide effective rail, road and costal connections from the waterways for the emergence of multi-modal logistics solutions. The terminals should be located close to industrial hubs or consumption centres and should provide connectivity with both rail and Road. Connectivity with Coastal shipping is possible at all National Waterways. Kolkata and Paradip port on eastern side. Cochin and Goa port on western side can be seamlessly connected with IWT. The integration of inland waterways with coastal shipping is dependent on Infrastructural linkages, Vessel and Terminal Operational aspects and Regulatory framework allowing the inter-modal (sea-river-waterway) flow of the vessels [50].

e) Vessel Availability: Strong steps need to be taken to encourage vessel availability in India. Revival of Vessel Building Subsidy scheme [51], abatement of service tax, granting of vessel building an "infrastructure' status", guaranteeing two way cargo to vessel operators, round the year LAD availability, viability gap funding, Special Purpose Vehicle for vessel leasing, multiple MRO facilities are some of the possible steps which can be taken to ensure vessel availability on Indian waters.

f) Modal Shift Incentives: Incentivise modal shift to IWT. Government can either offer cash incentives for modal shift to IWT. Alternatively Govt can monetize the environmental advantages of IWT by offering Renewable Energy Certificates (REC). Government can also perhaps take a target of modal split. The current modal split in India is heavily skewed towards road and there is urgent need to correct this towards better modes like IWT, Coastal and Rail.

g) Cargo focus: Govt should target specific cargo like Coal [52], Cement, fly ash, Fertilizers, Food grains and ODC. All the users of these cargo close to National Waterways need to be met, their requirements to be understood and specific solutions to be developed for them on long term basis.

h) Larger Allocation of funds: The allocation of funds to IWT has been meagre compared to Road and Rail. The cost of developing and maintaining IWT is much less compared to 
Road and Rail. A same quantum of fund allocated to all three modes will result in development of much larger KM of IWT. It is high time that there is a quantum jump in the funds allocated to IWT in 12th and 13th Five Year Plans.

i) Speed of Implementation: The pace of project implementation is far from desired. Even after 30 years of its declaration we are still not able to provide LAD of $3 \mathrm{~m}$ on whole stretch of NW1. There is lot to learn from China in this regard. The projects need to be time bound and implemented with urgency.

j) Targets for IWT mode: There should be specific target for cargo carried on IWT by year 2025 indicated in terms of BTKM. All planning should be done backwards to achieve this BTKM target.

k) International Cooperation: The Indo Bangladesh Protocol should be extended for minimum 10 years to avoid any uncertainty to the users and encourage long term planning. India should continuously provide support to Bangladesh for the dredging activity and maintenance of fairway.

l) RIS on all Waterways: RIS should be implemented on all National Waterways.

\section{CONCLUSION}

IWT continues to be an insignificant mode in India in spite of various efforts being made by IWAI in last 30 years. As compared to other countries including China there is lot of catching up to being done. The awareness of IWT as a mode with shippers continues to be low and does not figure in the scheme of supply chain planning for them. The success of NTPC Farakka project or Goa Iron Ore Transportation system brings a lot of learning. IWAI should:

a) Focus its energy on one National Waterway preferably NW1,

b) Identify the potential commodities on the National Waterways,

c) Develop commodity specific solutions,

d) Provide consistent LAD of 2.5 to $3 \mathrm{~m}$ with round the clock and round the year services and

e) Create two way loads or provide assurance for return cargo.

The development of additional 106 more National Waterways may not fetch the desired results. It will rather dilute the efforts of IWAI.

At the policy level navigation has to be accorded adequate consideration while deciding on the use of river water. The construction of dams, barrages, bridges should consider navigation as an important requirement and make provisions for it.

The governance structure of IWT is too centralised with all efforts being made at Central level with no involvement and support of States. State Governments should be encouraged to create an IWT department in each state and try to develop State Waterways in line with State Highways. This will provide impetus to National waterways and create feeder routes and feeder cargo.

Use IWT as a supplementary mode of transportation. A tie up with industrial location policy to drive would be essential.

The compartmented approach which Govt has been following may not be effective. We have separate ministries for various modes of transport from shipping, Road and Rail. There is need to have a holistic view of the transportation needs in the country and a holistic solutions combining all modes including IWT and Coastal shipping. 
Jim Watkins has said 'A river cuts through a rock, not because of its power, but because of its persistence'. India too need to persist with IWT, overcome the rocks on the way and someday realise the true power of Inland Waterways.

\section{References}

1. Inland Waterways Authority of India (IWAI). Home, [Online]. Available: (www.iwai.nic.in).

2. Sriraman S, January 2010, Long Term Perspectives on Inland Water Transport in India, RITES Journal.

3. Planning Commission, 2013, 12th Fiver Year Plan, New Delhi.

4. Bansal AK, India's Maritime Heritage.

5. Biswas, A. K. (1992) "Indus Water Treaty: the Negotiating Process”, Water International, 201-209.

6. Nagabhatla Nidhi, 2013, Assessing the Potential Role of Inland Water Navigation for Green Economy, Journal of Environmental Professionals, Sri Lanka: Vol. 2 - No. 1, 25-37.

7. Mishra, D. K. and Hussain, S. M., (2012), Situation Analysis on Inland Navigation, Ecosystems for Life: A Bangladesh-India Initiative, IUCN, and International Union for Conservation of Nature.

8. Report of the National Transport Policy Committee', 1980, Planning Commission, Government of India, New Delhi.

9. Directorate General of Shipping (2009) “Annual Report [2009-10]”, Government of India.

10. KPMG Report, 2014, Water Transportation in India.

11. IWT Policy (2001), IWAI website, Available on iwai.nic.in.

12. Rangaraj, N, and Raghuram, G., 2007, Viability of Inland Water Transport in India, INRM Policy Brief, Asian Development Bank, New Delhi.

13. Government of India, (2007), Gazette Notification date 20th to 26th January 2007, Ministry of Shipping, Road Transport and Highways, Inland Waterways Authority of India.

14. Ministry of Shipping, Website: shipping.nic.in.

15. IWAI presentation, (2015), Inland Water Transport in India.

16. Central Inland Water Transport Corporation Limited (CIWTC) Website: ciwtcltd.com.

17. The Economic Times, (2016), Government nod to dissolution of Central Inland Water Transport Corporation.

18. The National Inland Navigation Institute (NINI) Website: http://www.nini.bih.nic.in/. 
19. The DNA, 2016, Parliament approves National Waterways Bill to develop 111 rivers as transport routes.

20. Government of India (2016), Gazette Notification date March 26th 2016, Ministry of Law and Justice.

21. Government of India, 1950, Government of India's Resolution setting up the Planning Commission, New Delhi.

22. Planning Commission.1950, 1st Five Year Plan, and New Delhi.

23. Planning Commission. 1956, 2nd Five Year Plan, New Delhi.

24. Planning Commission. 1961, 3rd Five Year Plan, NewDelhi.

25. Planning Commission. 1969, 4th Five Year Plan, New Delhi.

26. Planning Commission.1974, 5th FiveYear Plan, and New Delhi.

27. Planning Commission. 1983, 6th Mid Term Appraisal, New Delhi.

28. Planning Commission.1980, 6th Five Year Plan, and New Delhi.

29. Planning Commission. 1992, 8th Five Year Plan, New Delhi.

30. Planning Commission. 1997, 9th Five Year Plan, New Delhi.

31. Planning Commission. 2002-2007, 10th Five Year Plan, New Delhi.

32. Planning Commission, 2007, 11th Five Year Plan, Planning Commission, New Delhi.

33. Planning Commission, 2013, 12th Five Year Plan, Planning Commission, New Delhi.

34. Government of India, Guidelines for Central Sector (CS) Scheme for Inland Water Transport (IWT) sector for the North Eastern Sates including Sikkim, Ministry of Shipping, Road Transport and Highways, Department of Shipping IW-14013/1/2008IWT.

35. IWAI presentation (2015), Importance of Inland Water Transport for North East, FICCI Summit, Shillong.

36. Government of India, Mar 2015, Ministry of Shipping, Press Information Bureau, Jal Marg Vikas Project.

37. Cochin Port Trust, Commissioning of the Ro-Ro Terminal Jetty at Bolghatty and Willingdon Island., http://cochinport.gov.in/.

38. Government of India, 2015, Implementation of the Kaladan Multi Modal Transit Transport Project in Myanmar at the Revised Cost Estimate of Rs 2904.04 Crore, Press Information Bureau, Cabinet.

39. GOI 2015, MoU signed between Inland Waterways Authority and Dedicated Freight Corridor Corporation for logistic hubs with rail connectivity, Press Information Bureau, Ministry of Shipping. 
40. RITES Ltd 2013, Preparation of Integrated National Inland Waterways Transport Grid, IWAI Website, Available on iwai.nic.in.

41. Government of India, Ministry of Shipping 2014, Report of the Committee on Standard for Coastal and Inland Vessels; Sea limits for Inland Vessels; and incentives scheme for modal sift of cargo from Road/Rail to Waterways.

42. Government of India, Ministry of Shipping, 2016, Press Information Bureau, 'Scheme for Incentivizing Modal Shift of Cargo'.

43. Paul Amos,,Jia Dashan,Ning Tao,Sun Junyan \& FEI Weijun, May 2009, Sustainable development of Inland waterway transport in China, (Theme I of a World Bank Project: Comprehensive Transport System Analysis in China - P109989), .

44. Government of India Maritime Agenda, 2011-2020, January 2011, Ministry of Shipping, p-414.

45. Sarma K G S, July 2010, “India’s National Waterways: A long Way to Go” Rites Journal.

46. Planning Commission (2006) "Report of the Working Group on Water Resources for the XI Five year Plan 2007-2012"New Delhi, India.

47. Patra Sunakar, 2015, Inland Waterways as a Potential Catalyst for the Development of Odisha, International Journal of Research Link.

48. Singh Vijaya, July 2010, India Needs an Integrated Transport Plan, Rites Journal.

49. Mishra Amit, Saxena Alipt, Khanapuri V.B., Evaluating Development Opportunities for Inland Water Transport in India, Conference Paper.

50. Deloitte 2011, Preparation of strategy road map cum action plan for development of coastal shipping in Kerala.

51. Mittal Juhi, 2013, Nationalization if Inland Water Navigation, Centre for Urban Studies Working Paper Series.

52. IWAI presentation (2010), Coal Movement on Ganga (NW1). 